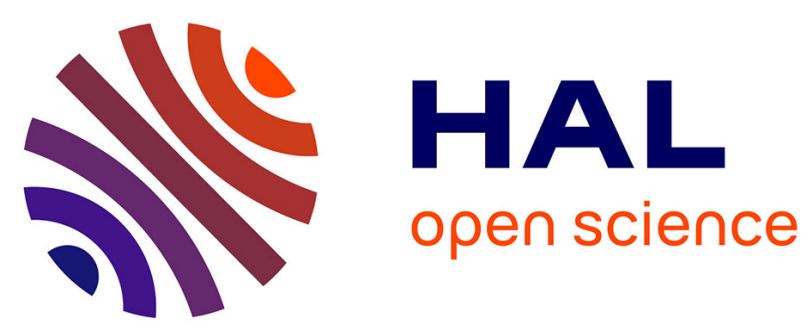

\title{
Large-scale displacement along the Altyn Tagh Fault (North Tibet) since its Eocene initiation: Insight from detrital zircon $\mathrm{U}-\mathrm{Pb}$ geochronology and subsurface data
}

Feng Cheng, Marc Jolivet, Suotang Fu, Changhao Zhang, Qiquan Zhang, Zhaojie Guo

\section{- To cite this version:}

Feng Cheng, Marc Jolivet, Suotang Fu, Changhao Zhang, Qiquan Zhang, et al.. Large-scale displacement along the Altyn Tagh Fault (North Tibet) since its Eocene initiation: Insight from detrital zircon U-Pb geochronology and subsurface data. Tectonophysics, 2016, 677-678, pp.261-279. $10.1016 / j$.tecto.2016.04.023 . insu-01312745

HAL Id: insu-01312745

https://hal-insu.archives-ouvertes.fr/insu-01312745

Submitted on 20 May 2016

HAL is a multi-disciplinary open access archive for the deposit and dissemination of scientific research documents, whether they are published or not. The documents may come from teaching and research institutions in France or abroad, or from public or private research centers.
L'archive ouverte pluridisciplinaire HAL, est destinée au dépôt et à la diffusion de documents scientifiques de niveau recherche, publiés ou non, émanant des établissements d'enseignement et de recherche français ou étrangers, des laboratoires publics ou privés. 
1 Large-scale displacement along the Altyn Tagh Fault (North Tibet) since its

2 Eocene initiation: insight from detrital zircon U-Pb geochronology and

3 subsurface data

4

5 Feng Cheng ${ }^{1,2}$, Marc Jolivet ${ }^{2}$, Suotang $\mathrm{Fu}^{3}$, Changhao Zhang ${ }^{3}$, Qiquan Zhang ${ }^{3}$,

6 Zhaojie Guo ${ }^{1, \dagger}$

7

$8{ }^{1}$ Key Laboratory of Orogenic Belts and Crustal Evolution, Ministry of Education,

9 School of Earth and Space Sciences, Peking University, Beijing, 100871, China

$10 \quad{ }^{2}$ Laboratoire Géosciences Rennes, CNRS-UMR6118, Université Rennes 1 -

11 Observatoire des Sciences de l'Univers, Rennes, 35042, France

${ }^{3}$ Qinghai Oilfield Company, PetroChina, Dunhuang, Gansu, 736202, China

${ }^{\dagger}$ Corresponding author. Tel.: + 86-10-62753545; fax: + 86-10-62758610. E-mail address: zjguo@pku.edu.cn (Z.J.Guo) 


\section{Abstract}

Marking the northern boundary of the Tibetan plateau, the Altyn Tagh fault plays a crucial role in accommodating the Cenozoic crustal deformation affecting the plateau. However, its initiation time and amount of offset are still controversial despite being key information for the understanding of Tibet evolution. In this study, we present 1122 single LA-ICP-MS detrital zircon U-Pb ages obtained from 11 Mesozoic to Cenozoic sandstone samples, collected along two sections in the northwestern Qaidam basin (Eboliang and Huatugou). These data are combined with new 3D seismic reflection profiles to demonstrate that: (1) From the Paleocene to early Eocene, the Eboliang section was approximately located near the present position of Anxi, $360 \pm 40 \mathrm{~km}$ southwest from its current location along the Altyn Tagh fault, and sediments were mainly derived from the Altyn Tagh Range. At the same period, the Huatugou section was approximately located near the present position of Tula, ca. $360 \mathrm{~km}$ southwest from its current location along the Altyn Tagh fault, and the Eastern Kunlun Range represented a significant sediment source. (2) Left-lateral strike-slip movement along the Altyn Tagh fault initiated during the early-middle Eocene, resulting in northeastward displacement of the two sections. (3) By early Miocene, the intensive deformation within the Altyn Tagh Range and northwestern Qaidam basin strongly modified the drainage system, preventing the materials derived from the Altyn Tagh Range to reach the Eboliang and the Huatugou sections. The post-Oligocene clastic material in the western Qaidam basin is generally 
derived from local sources and recycling of the deformed Paleocene to Oligocene strata. From these data, we suggest enhanced tectonic activity within the Altyn Tagh

Range and northwestern Qaidam basin since Miocene time, and propose an early-middle Eocene initiation of left-lateral strike-slip faulting leading to a $360 \pm 40$ km offset along the Altyn Tagh fault.

Keywords: Detrital zircon U-Pb geochronology, Cenozoic tectonics, North Tibet, Altyn Tagh fault, Qaidam basin.

\section{Introduction}

Two competing end-member mechanisms have been proposed to explain the accommodation of the ongoing convergence between India and Eurasia since the early Eocene collision: (1) a homogeneous crustal thickening of the Tibetan plateau (e.g. England and Houseman, 1989; Searle, 1996); and (2) an eastward extrusion of the Tibetan plateau and southeast Asia away from the indenting Indian plate (Molnar and Tapponnier, 1975; Peltzer and Tapponnier, 1988; Avouac and Tapponnier, 1993; Tapponnier, et al., 2001). The second model requires large-scale displacement along lithospheric strike-slip fault zones to allow extrusion of the Tibetan crust (e.g. Searle, 1996; Tapponnier, et al., 2001). Marking the northern boundary of the Tibetan plateau (Fig. 1), the lithospheric-scale left-lateral strike-slip Altyn Tagh fault (ATF) plays a crucial role in accommodating the crustal deformation and appears to be an ideal field laboratory for ascertaining the dynamics of plateau formation (Molnar and 
Tapponnier, 1975; Wittlinger et al., 1998; Jolivet et al., 1999, 2001; Yin and Harrison, 2000; Yin et al., 2002; Searle et al., 2011). Understanding the kinematic pattern of the ATF, especially the exact Cenozoic initiation time and the amount of Cenozoic offset, is of major importance for unraveling the crustal accommodation processes within the plateau since the India-Eurasian collision and for deciphering the growth history of the entire Tibetan plateau.

Several authors proposed that a large scale Jurassic basement cooling event associated to tectonic exhumation affected a corridor along the ATF (e.g. Delville et al., 2001; Sobel et al., 2001; Wang et al., 2005). In addition, many researchers consider that deformation along the ATF initiated after the late Mesozoic, during the early Cenozoic, or even during the Neogene (e.g. Tapponnier et al., 1986; Jolivet et al., 1999; Chen et al., 2001; Jolivet et al., 2001; Yin et al., 2002; Wang et al., 2006a; Wu et al., 2012a, 2012b; Zhang et al., 2012, 2014a). Similarly, estimations of the total displacement along the ATF vary widely from 1200 km to less than $90 \mathrm{~km}$ (e.g. Tapponnier et al., 1986; Wang, 1997; CSBS, 1992; Ritts and Biffi, 2000; Yin and Harrison, 2000; Yang et al., 2001; Yue et al., 2001; Chen et al., 2002; Yin et al., 2002; Cowgill et al., 2003; Gehrels et al., 2003a, 2003b; Darby et al., 2005; Yue et al., 2005; Searle et al., 2011; Cheng et al., 2015a). These tremendous discrepancies may be partially attributed to the immense size and extent of the Altyn Tagh Range, making it difficult to locate ideal piercing points to estimate the total displacement along the ATF. Furthermore, due to strong Cenozoic deformation, continuous Mesozoic to Cenozoic stratigraphic sections necessary to estimate the time of initiation of 
left-lateral slip movement are seldom preserved (e.g. Yin and Harrison, 2000; Cheng et al., 2015a).

Detrital zircon analysis of a continuous, well dated stratigraphic succession has become a powerful tool for unraveling source to sink relationships and constraining the tectonic and topographic evolution of an area (e.g. Fedo et al., 2003; Thomas, 2011; Gehrels, 2014). To bring more constraints on the kinematic evolution of the ATF, we conducted an integrated analysis on two Jurassic to Pleistocene sedimentary sections in the western part of the Qaidam basin, adjacent to the ATF (Fig. 2). We then combined the detrital zircon $\mathrm{U}-\mathrm{Pb}$ geochronology data obtained from these sections with high-quality subsurface data, including newly acquired seismic profiles and drill core sandstone samples.

\section{Geological Background}

\subsection{Altyn Tagh Range}

The Altyn Tagh Range is located along the northern edge of the Tibetan plateau, separating the Tarim basin to the northwest from the Tibetan plateau and the Qaidam basin to the south (Figs. 1 and 2). The bedrock of the Altyn Tagh Range mainly consists of Precambrian igneous and metamorphic rocks and Paleozoic igneous and sedimentary rocks (e.g. Sobel and Arnaud, 1999; Yin et al., 2002). It has been shown that the Altyn Tagh Range experienced multiple-stage deformation and tectonic exhumation from the Jurassic to the Holocene (Tapponnier et al., 1986; Jolivet et al., 1999; Yue and Liou, 1999; Chen et al., 2001; Delville et al., 2001; Jolivet et al., 2001; 
Sobel et al., 2001; Yin et al., 2002; Wang et al., 2005, 2006a; Zhang et al., 2012).

Within this range, the over $1600 \mathrm{~km}$ long ENE-trending ATF links the western

Kunlun thrust belt to the southwest and the Qilian Shan thrust belt to the northeast

(Fig. 1; Burchfiel et al., 1989; Wang, 1997; Yue and Liou, 1999; Yin and Harrison, 2000; Yin et al., 2002). Although Mesozoic shearing occurred in the Altyn Tagh

Range, the growth of the northern Tibetan plateau is largely influenced by Cenozoic sinistral strike-slip faulting along the ATF (Tapponnier et al., 1986, 2001; Arnaud et al., 2003; Wang et al., 2005; Li et al., 2006; Liu et al., 2007). As previously mentioned, the estimation of the total displacement along the fault remains heavily debated, varying from about $1200 \mathrm{~km}$ to less than 90 km (e.g. CSBS, 1992; Ritts and Biffi, 2000; Yang et al., 2001; Chen et al., 2002; Cowgill et al., 2003; Gehrels et al., 2003a, 2003b; Yue et al., 2005; Cheng et al., 2015a).

\subsection{Qaidam basin}

The rhomb-shaped Qaidam basin is the largest petroliferous basin within the entire Tibetan plateau (Figs. 1 and 2). Geomorphologically, the basin is surrounded by the Altyn Tagh Range to the northwest, the Qilian Shan to the northeast and the Eastern Kunlun Range to the south. Geological mapping and petroleum exploration revealed that the Qaidam basin is filled with Mesozoic to Cenozoic clastic sediments unconformably overlying a poorly documented basement (Xia et al., 2001; Meng and Fang, 2008; Yin et al., 2008a, 2008b; Zhang et al., 2013a). The Mesozoic strata, especially the Jurassic and lower Cretaceous sequences, are mainly distributed along the foreland of both the Altyn Tagh Range and the Qilian Shan (Ritts et al., 1999; Wu 
et al., 2011), while the Cenozoic series are generally deposited over the entire basin (Yin et al., 2008b). The Cenozoic sedimentation pattern is largely controlled by a succession of depocenters consistently located along the long axis of the basin and gradually migrating eastward since Eocene times, indicating the gradual uplift of the Altyn Tagh Range (Fig. 1; Song and Wang, 1993; Qiu, 2002; Sun et al., 2005; Wang et al., 2006a; Yin et al., 2008b). Using magnetostratigraphy, palynology and paleontology, the Mesozoic-Cenozoic strata have been precisely subdivided into 11 chronostratigraphically constrained units (Fig. 3; Huo, 1990; QBGMR, 1991; Yang et al., 1992; Huang et al., 1996; Xia et al., 2001; Qiu, 2002; Deng et al., 2004a, 2004b; Sun et al., 2005; Zhang, 2006; Zhao et al., 2006; Fang et al., 2007; Sun et al., 2007; Yin et al., 2008b; Gao et al., 2009; Pei et al., 2009; Lu and Xiong, 2009; Ke et al., 2013). These units are: (1) the Dameigou Formation, $J_{1+2} d$; (2) the Caishiling Formation, $\mathrm{J}_{3} \mathrm{C}$; (3) the Quanyagou Formation, Kq; (4) the Lulehe Formation, $\mathrm{E}_{1+2} \mathrm{l}$, >53.5 - 43.8 Ma (Yang et al., 1992; Zhang, 2006; Ke et al., 2013); (5) the lower Xiaganchaigou Formation, $\mathrm{E}_{3}{ }^{1}$ xg, 43.8 - 37.8 Ma (Zhang, 2006; Sun et al., 2007; Pei et al., 2009); (6) the upper Xiaganchaigou Formation, $E_{3}{ }^{2} \mathrm{xg}, 37.8$ - 35.5 Ma (Sun et al., 2005; Sun, 2007; Pei et al., 2009); (7) the Shangganchaigou Formation, $\mathrm{N}_{1} \mathrm{sg}, 35.5$ - 22.0 Ma (Sun et al., 2005; Lu and Xiong, 2009); (8) the Xiayoushashan Formation, $\mathrm{N}_{2}{ }^{1} \mathrm{xy}, 22.0$ - 15.3 Ma (Fang et al., 2007; Lu and Xiong, 2009); (9) the Shangyoushashan Formation, $\mathrm{N}_{2}{ }^{2}$ sy, 15.3 - 8.1 Ma (Fang et al., 2007); (10) the Shizigou Formation, $\mathrm{N}_{2}{ }^{3}$ s, 8.1 - 2.5 Ma (Fang et al., 2007); (11) the Quaternary deposits, including the Qigequan Formation $\left(\mathrm{Q}_{1} \mathrm{q}\right)$ and the Dabuxun-Yanqiao 
Formation ( $\left.\mathrm{Q}_{2} \mathrm{~d}\right), 2.5$ - $0.01 \mathrm{Ma}$ (Fang et al., 2007; Yin et al., 2008b). Effective elastic thickness calculation implies that the mechanical strength of the Qaidam crust is exceptionally strong compared to the rest of the Tibetan plateau (Braitenberg et al., 2003). Based on balanced cross section results, Zhou et al. (2006) proposed that the Qaidam basin experienced an average of 10\% of NE-SW shortening during the Cenozoic, whereas Yin et al. (2008b) suggested that the shortening strain across the basin decreases systematically eastward from ca. $48 \%$ in the west, to ca. $11 \%$ in the center, and $<1 \%$ in the east.

\section{Stratigraphy and sedimentary characteristics of the studied sections}

In this study, the Eboliang and Huatugou sections, situated along the eastern and central segments of the ATF, have been chosen for their exceptional preservation and exposure of the Jurassic to Pleistocene sedimentary series (Figs. 2 and 3). In order to give a continuous description of the Jurassic to Quaternary sediment evolution of the northwestern Qaidam basin, we constructed the Eboliang and Huatugou sections based on the lithologies, sediment facies and paleocurrent directions obtained from fieldwork, drill-core and literature data as summarized in the Figure 3 and in the text below. The stratigraphy of the Huatugou and Eboliang sections has already been established by previous field geological studies which give age constrains based on fossil assemblages, distinctive lithology feature, magnetostratigraphy, palynology and paleontology (e.g. XBGRM, 1993; HGSI, 2003; IGSQP, 2004). Consequently, we follow the previous division of formations. 


\subsection{Eboliang section}

The Eboliang section is located along the southern flank of the Altyn Tagh Range (Fig. 2). The upper Jurassic-Cretaceous strata are missing, and the Paleogene deposits rest unconformably on lower - middle Jurassic series. Except for the absence of the Paleocene Lulehe Formation, the Cenozoic sequence is complete and exceptionally well exposed.

High-quality seismic profiles and drill core data reveal that the base of the Eboliang section is formed by the lower to middle Jurassic Dameigou Formation $\left(\mathrm{J}_{1+2} \mathrm{~d}\right)$, resting unconformably on the basement rocks (Yin et al., 2008). This Jurassic sequence generally contains a succession of three well-developed fining upward cycles. Each cycle characteristically begins with medium- to coarse-grained sandstone deposits (Fig. 4A), fining upwards to silty mudstone. The sequence, as in general for the Qaidam basin, is considered to represent shore shallow lacustrine facies at the base, evolving into flood plain sediments upward (Ritts et al., 1999; Ritts and Biffi, 2000; Wu et al., 2011; Jian et al., 2013). Trough and planar cross-stratification and clast imbrication from those Jurassic fluvial strata indicates northward paleoflows (Fig. 3; Ritts and Biffi, 2000).

The entire upper Jurassic and Cretaceous sequence is missing and the Paleocene Lulehe Formation $\left(\mathrm{E}_{1+2} \mathrm{l}\right.$,) unconformably overlies the lower and middle Jurassic series (Wu et al., 2011). The strata are composed of dark brown mudstone (Fig. 4B) and sandy mudstone intercalated with gray siltstone at the base, evolving towards brown pebbly sandstone intercalated with conglomerates and gypsum-salt layers in 
the middle and upper parts of the section. The Lulehe Formation is generally interpreted as braided river and alluvial fan depositional environments (Zhuang et al., 2011; Jian et al., 2013; Song et al., 2013). Based on heavy mineral contents, calculated zircon-tourmaline-rutile (ZTR) indices, and the heavy mineral assemblages from drill-core samples from a large number of oil wells in the Eboliang section, Fu et al. (2013) suggested that during the deposition of the Paleocene-early Eocene Lulehe Formation, the material deposited in the Eboliang area was derived from the north, probably from the Altyn Tagh Range.

The Eocene to Oligocene strata of the Xiaganchaigou Formation unconformably rest on the Lulehe Formation. The strata are mainly composed of grey and brown sandstone (Fig. 4C) and conglomerate at the bottom corresponding to alluvial facies deposits (Zhuang et al., 2011; Jian et al., 2013; Wang et al., 2013) and contain a succession of fining upward cycles. The middle part of the Xiaganchaigou Formation is dominated by brownish red mudstone and sandy mudstone intercalated with gray calcareous mudstone and marlstone. The upper part of the Xiaganchaigou Formation, however, is dominated by variegated mudstone intercalated with thin-layers of sandy conglomerate, sandstone and limestone, generally associated to a lacustrine depositional environment (Zhuang et al., 2011; Jian et al., 2013; Wang et al., 2013). Conglomerate fabrics in the Eboliang area show north-directed or south-directed bilateral paleoflows, suggesting a low-energy lacustrine-offshore environment at the time (Fig. 3; Wu et al., 2012b).

The Oligocene Shangganchaigou Formation $\left(\mathrm{N}_{1} \mathrm{sg}\right)$, conformably rests on the 
Xiaganchaigou Formation. It consists of brownish red, gray siltstone, grey mudstone, sandy mudstone and siltstone, intercalated with gray sandstone and marlstone (Fig. 4D) mostly corresponding to lacustrine sediment facies (Zhuang et al., 2011; Jian et al., 2013; Wang et al., 2013). Paleocurrents measured from the conglomerate fabrics become dominantly south-directed away from the Altyn Tagh Range (Fig. 3; Wu et al., 2012b).

The early Miocene Xiayoushashan Formation $\left(\mathrm{N}_{2}{ }^{1} \mathrm{xy}\right)$ conformably lies on the Shangganchaigou Formation. The lower part of the formation is composed of gray and brownish red mudstone and sandy mudstone intercalated with gray siltstone, grayish yellow sandstone and grayish brown marlstone. It evolves upwards to gray mudstone, argillaceous sandstone and argillaceous siltstone intercalated with grey siltstone, brownish red mudstone and gray marlstone (Fig. 4E). The early Miocene sequence in the north Qaidam basin is generally considered as deposited in a fluvial to marginal lacustrine environment (Zhuang et al., 2011; Jian et al., 2013; Wang et al., 2013). Conglomerate fabrics in the section suggest south-directed paleocurrents during the early Miocene (Fig. 3; Wu et al., 2012b).

The late Miocene Shangyoushashan Formation $\left(\mathrm{N}_{2}{ }^{2}\right.$ sy) conformably rests on the Xiayoushashan Formation. The deposits are mainly composed of grey mudstone and sandy mudstone intercalated with grey argillaceous sandstone, argillaceous siltstone, grayish yellow marlstone and some limited gray sandy limestone corresponding again to a fluvial to marginal lacustrine environment (Zhuang et al., 2011; Jian et al., 2013; Wang et al., 2013). Paleocurrent measurements from the sandstone layers around the 
Eboliang area indicate southwest-directed paleoflows (Fig. 3; Wu et al., 2012b).

The Pliocene Shizigou Formation $\left(\mathrm{N}_{2}{ }^{3} \mathrm{~s}\right)$ generally conformably and locally unconformably rests on the Shangyoushashan Formation. The series are composed of gray mudstone and silty mudstone intercalated with brown siltstone, pebbly sandstone and gypsum-salt layers. They are generally interpreted as deposited in a marginal lacustrine to alluvial fan environment (Fig. 4F; Zhuang et al., 2011; Heermance et al., 2013; Jian et al., 2013; Wang et al., 2013). Trough cross-bedding within the strata suggests generally southwestward paleoflows during the Pliocene (Fig. 3; Heermance et al., 2013).

Finally, the Pleistocene sequence, dominated by the Qigequan Formation $\left(\mathrm{Q}_{1} \mathrm{q}\right)$, unconformably overlies the Shizigou Formation. The sediments are characterized by brown sandstone, pebbly sandstone and conglomerate intercalated with gypsum layers, corresponding to fluvial to evaporatic lacustrine facies (Heermance et al., 2013; Jian et al., 2013). Well-developed cross-beddings within the strata show primarily southward unidirectional paleocurrents (Fig. 3; Heermance et al., 2013).

\subsection{Huatugou section}

The Huatugou section is located in the northernmost part of the prominent Yingxiongling uplift structure (Fig. 2). Except again for the Paleocene Lulehe Formation, the whole Mesozoic-Cenozoic sequence is well exposed (Figs. 2 and 3).

Subsurface data reveal that the Jurassic clastic coal-bearing strata rest unconformably on the Altyn Tagh Range basement (Xia et al., 2001; Yin et al., 2008). The Dameigou Formation $\left(\mathrm{J}_{1+2} \mathrm{~d}\right)$ is dominated by a set of sandstone beds interbedded 
with conglomerate, siltstone and mudstone (Ritts et al., 1999; Ritts and Biffi, 2000). The sediment facies vary from fluvial to shallow lake deposits (Ritts and Biffi, 2000). Trough and planar cross-stratification as well as clast imbrication within the strata indicate northward paleoflows during the Jurassic (Fig. 3; Ritts and Biffi, 2000).

Based on the subsurface data (core and seismic profile data), the Paleocene to early Eocene Lulehe Formation $\left(\mathrm{E}_{1+2} \mathrm{l}\right)$ is dominated by successions of purple-red conglomerate interbedded with sandstone at the base, evolving upward towards grey sandstone, siltstone and sandy mudstone. The sediment facies vary from fluvial to shallow lake deposits upward and basinward (Fu et al., 2013; Li et al., 2015). Heavy mineral contents in surface samples, calculated zircon-tourmaline-rutile (ZTR) indices, and the heavy mineral assemblages from the drill-core samples from a large number of oil wells in the Huatugou area suggest that during the deposition of the Paleocene-early Eocene Lulehe Formation, the material deposited in that area was mainly derived from the southwest, probably from the Eastern Kunlun Range (Fu et al., 2013; Li et al., 2015).

The middle Eocene lower Xiaganchaigou Formation $\left(\mathrm{E}_{3}{ }^{1} \mathrm{xg}\right)$ is mainly composed of grey-green, brownish-red sandstone and pebbly sandstone at the base, evolving upward towards brown red sandstone and siltstone (Fig. 4G). The sediment facies vary from fluvial to shallow lacustrine deposits upward (Zhuang et al., 2011; Wu et al., 2012a, 2012b). Paleocurrents measurements based on pebble imbrication and cross-stratification in the fluvial sandstone layers indicate NE-directed paleoflows (Fig. 3; Meng and Fang, 2008). 

lower Xiaganchaigou Formation. This sequence is dominated by successions of grey-green, brownish-red mudstone and carbonaceous siltstone, intercalated with argillaceous siltstone and marlstone (Fig. 4H). The sediment facies vary upward from braided river to shallow lake deposits (Wu et al., 2012a, 2012b). Clast imbrications within the fluvial strata suggest that paleocurrents were directed towards the south during the deposition of the upper Xiaganchaigou Formation. (Fig. 3; Wu et al., 2012a). 
shallow lake, alluvial plain and braided river deposits (Wu et al., 2012a, 2012b). Clast imbrication as well as trough (and lesser planar) cross-stratification within the layers in the section suggest generally northwestward paleoflows (Zhuang et al., 2011).

The Shizigou Formation $\left(\mathrm{N}_{2}{ }^{3} \mathrm{~s}\right)$, again lying unconformably on the Shangyoushashan Formation, is mainly composed of earth-yellow sandstone and silty mudstone corresponding to fluvial facies sediments (Wu et al., 2012a, 2012b). Paleocurrents from clast imbrications indicate generally south-directed paleoflows away from the Altyn Tagh Range during the deposition of the Shizigou Formation (Fig. 3; Zhuang et al., 2011).

The Qigequan $\left(\mathrm{Q}_{1} \mathrm{q}\right)$ and Dabuxun-Yanqiao $\left(\mathrm{Q}_{2}\right)$ formations, unconformably overly the Shizigou Formation, and mainly consists of grey and brown sandstone and conglomerate corresponding to flood plain and alluvial facies deposits.

\section{Methods and analytical procedures}

\subsection{Detrital zircon geochronology}

Detrital zircon U-Pb geochronology has rapidly developed into a very powerful tool for determining sediment provenances (e.g. Fedo, et al., 2003; Thomas, 2011; Liu et al., 2013; Yang et al., 2013; Gehrels et al., 2014; Cheng et al., 2015a). By systematically comparing the detrital zircon $\mathrm{U}-\mathrm{Pb}$ age spectrum obtained from sedimentary sequences in basins with the known ages of potential source terranes, it is possible to describe the source to sink relations through time within a given area and to reconstruct the landscape evolution of the region (e.g. Fedo, et al., 2003; Gehrels et 
al., 2011; Thomas, 2011; Liu et al., 2013; Yang et al., 2013; Gehrels et al., 2014; Yang et al., 2014; Cheng et al., 2015a). In the Eboliang section, eight samples were collected, ranging in age from Jurassic to Pleistocene (Fig. 2), and including three samples from drill cores. In the Huatugou section, three core samples were obtained from drill wells, ranging in age from Paleocene to Oligocene. In order to derive a continuous Jurassic to Pleistocene source to sink relation between the Altyn Tagh 
grains, to correct for instrument fluctuations and determine fractionation factors. Zircons Qinghu and 91500 (Wiedenbeck et al., 1995) were the monitoring standards.

For elemental concentration analysis, NIST610 was the external standard, and ${ }^{29} \mathrm{Si}$ was the internal standard. Meanwhile, NIST612 and NIST614 were used as monitoring standards. The GLITTER 4.4 software was used to calculate the U-Pb isotope ratios and element contents (China University of Geosciences, Lab. of Prof. to describe the tectonic history of the western Qaidam basin. Seismic data were interpreted using the SMT Kingdom software. 


\section{U-Pb geochronology results of detrital zircons}

364

365

In general, about $90 \%$ of the zircon crystals are characterized by relatively distinct oscillatory zoning in CL images and relative high Th/U ratios, indicating a magmatic origin (Corfu et al., 2003; Hanchar and Rudnick, 1995; Hoskin and Black, 2000). The detrital zircons U-Pb ages vary widely between 2956 Ma and 57. Except for a single Cenozoic U-Pb age in sample EBLE, the detrital zircons U-Pb ages can be statistically subdivided into three groups of Precambrian (spanning from ca. 2.8 Ga to $550 \mathrm{Ma}$ ), early to middle Paleozoic (peaks at 460 400 Ma) and late Paleozoic to Mesozoic (peaks at ca. 260 240 Ma). Representative CL images of typical zircon grains are presented in Figure 5. U-Pb isotopic ages with errors and related raw data are listed in full in Appendix A. The statistical U-Pb geochronology data for each of the samples are listed in Table 1 and a detailed description of the zircons analyzed in each sample is given in Appendix B. Concordia plots for the eleven samples are shown in Figure 6. The zircon age spectrum of the samples from the Eboliang and Huatugou sections are shown in Figures 7 and 8, respectively. In the following, major age groups and their corresponding peak ages have been established from visual inspection of the detrital zircon $\mathrm{U}-\mathrm{Pb}$ age probability plots for all the samples. Age peaks are considered major when including at least $20 \%$ of the total number of data spread over less than $250 \mathrm{Ma}$, whereas a minor peak refers to populations representing less than $20 \%$ of the total number of data distributed over more than $300 \mathrm{Ma}$. 


\section{Discussion}

384

6.1 Geochronological characteristics of potential sources for the sedimentary rocks in the western Qaidam basin

The Altyn Tagh Range, the Qilian Shan, as well as the Eastern Kunlun Range are all potential source regions likely to provide zircons to the Qaidam basin (e.g.

Métivier et al., 1998; Xia et al., 2001; Meng and Fang, 2008; Yin et al., 2007, 2008a, 2008b). In order to better constrain the provenance area of the samples collected in the western Qaidam basin (Fig. 9A), we compiled the zircon U-Pb ages available on basement rocks of the Altyn Tagh Range (Fig. 9B), the Qilian Shan (Fig. 9C) and the Eastern Kunlun Range (Fig. 8D).

\subsubsection{Altyn Tagh Range}

In the Altyn Tagh Range, the basement mainly consists of Archean and Proterozoic rocks with Archean zircon U-Pb ages ranging from 3.6 Ga to 2.6 Ga (Lu and Yuan, 2003; Lu et al., 2008; Long et al., 2014; Zhang et al., 2014b and references therein), and Proterozoic zircon U-Pb ages ranging from $\sim 2.4 \mathrm{Ga}$ to 650 Ma (Gehrels et al., 2003a, 2003b; Wang et al., 2006b; Lu et al., 2008 and references therein; Zhang et al., 2011; Wang et al., 2013). A few scattered Neoproterozoic intrusions are exposed, with a large, distinctive early Neoproterozoic intrusion (ca. 850 Ma to ca. 1000 Ma in age) exposed west of the Xorkol basin (Fig. 9A). Wang et al. (2013) recently reported a mean crystallization age of 910 Ma for the basement rocks near the Anxi area, in the western part of the Altyn Tagh Range (Fig. 9A). 
404

405

406

407

408

409

410

411

412

413

414

415

416

417

418

419

420

421

422

423

424

425

Paleozoic intrusions with ages spanning from 550 Ma to 400 Ma are widely distributed (Jolivet et al., 1999; Sobel and Arnaud, 1999; Zhang et al., 2001; Cowgill et al., 2003; Gehrels et al., 2003a; Chen et al., 2004; Yue et al., 2004a, 2005; Yang et al., 2006; Wang et al., 2014b and references therein). Finally a few Permian igneous rocks are exposed along the central part of the Altyn Tagh Range, with zircon U-Pb ages ranging between $~ 300$ Ma and 260 Ma (Fig. 9A; Cowgill et al., 2003; Gehrels et al., 2003a; Gehrels et al., 2003b; Wu et al., 2014).

\subsubsection{Qilian Shan}

Zircon U-Pb ages from the North Qaidam and South Qilian Shan terranes mainly group between 2700 to 1100 Ma, 550 to 400 Ma, and 300 to 200 Ma (Fig. 9B; Yang and Song, 2002; Cowgill et al., 2003; Gehrels et al., 2003a, 2003b; Yue et al., 2005; Shi et al., 2006; Song et al., 2014 and references therein). The North Qilian Shan basement mainly consists of early Paleozoic marine strata associated with a series of Ordovician volcanics and Silurian granitic plutons (Bovet et al., 2009; Xiao et al., 2009; Song et al., 2014 and references therein). These granitoid intrusions yielded U-Pb zircon ages ranging from ca. 550 to ca. 440 Ma (Wu et al., 2001; Gehrels et al., 2003a, 2003b; Yue et al., 2005; Song et al., 2014 and references therein). Finally, the central Qilian Shan basement is composed of Mesoproterozoic to Neoproterozoic marine sequences intruded by early Paleozoic plutons, with detrital and plutonic zircon ages comprised between 2333 to 874 Ma and 442 to 424 Ma respectively (Guo and Li, 1999; Lu, 2002; Yue et al., 2005; Bovet et al., 2009; Song et al., 2014 and references therein). The Qilian Shan basement was affected by a Devonian phase of 
metamorphism (400-360 Ma), with a metamorphic peak at 440-423 Ma within the north Qaidam ultrahigh pressure belt (Yang et al., 2001, Yang and Song, 2002; Song et al., 2006; Yang et al., 2006; Song et al., 2014 and references therein). Finally, sporadically distributed late Permian to early Triassic granitoids are exposed along the western edge of the South Qilian Shan terrane, yielding zircon U-Pb ages ranging from ca. 270 Ma to ca. 230 Ma (Fig. 9A and 9C; Yang and Song, 2002; Wu et al., 2009; Dong et al., 2014, 2015).

\subsubsection{Eastern Kunlun Range}

Within the Eastern Kunlun Range, Proterozoic ages are rare (Fig. 9A and 9D). Several early Paleozoic intrusions with U-Pb zircon ages ranging from ca. 500 Ma to 400 Ma have been reported by previous studies (Fig. 9C; Cowgill et al., 2003; IGSQP, 2004; Dai et al., 2013; Li et al. 2013). Late Paleozoic - early Mesozoic granitoids (ca. 300 Ma to ca. $200 \mathrm{Ma}$ ), corresponding to the magmatism associated to the Permo-Triassic closure of the Paleo-Tethys Ocean and to the post-collision magmatism that followed the docking of the Qiangtang Block, are extensively distributed (Fig. 9A; e.g. Roger et al., 2003, 2008, 2010; Liu et al., 2006; Li et al., 2013; Jolivet et al., 2015; Chen et al., 2015). Finally, a few Cretaceous ages have been obtained from the Tula Uplift in the western reach of the Eastern Kunlun Range (Figs. 2A and 9A; Robinson et al., 2003; Cheng et al., 2015a) and some Miocene to Quaternary volcanism occurred in the southwestern part of the range (Jolivet et al., 2003). 
6.2 Provenance analyses of the Mesozoic-Cenozoic strata in the western Qaidam basin

\subsubsection{Eboliang section}

On a first order analysis, the detrital zircon $\mathrm{U}-\mathrm{Pb}$ age spectrum obtained from the eight samples collected on the Eboliang section are largely similar (Fig. 7), suggesting that the provenance area was largely homogeneous through time. However, second-order variations in age cluster proportions among those samples record source changes during basin filling. In general, the detrital zircons U-Pb ages can be statistically subdivided into three major groups of Precambrian (spanning from ca. 2.8 Ga to $550 \mathrm{Ma}$ ), early to middle Paleozoic (peaks at 460 400 Ma) and late Paleozoic to Mesozoic (peaks at ca. 260 240 Ma) (Fig. 7). Aside from these major groups, the restricted early Neoproterozoic age group spanning from ca. 850 to ca. 1100 Ma with a peak age around 911 Ma (for example in sample E123, Lulehe Formation) represents the contribution from a distinctive source in the Altyn Tagh Range that will be discussed in details below.

Based on isopachs distribution, the Jurassic depocenter was situated farther south of the Eboliang section, which rules out any contribution from the Eastern Kunlun Range in the Jurassic sediments from that section (Fig. 9A; also see Fig. 3b in Meng et al., 2001). We thus consider that the paleocurrents in the northwestern Qaidam basin (Ritts and Biffi, 2000) probably provided sediments from mixed sources both in the Qilian Shan and Altyn Tagh Range. Based on ${ }^{40} \mathrm{Ar} /{ }^{39} \mathrm{Ar}$ thermochronology as well as zircon and apatite fission track analysis, previous 
researches have reported Jurassic exhumation in the Altyn Tagh Range (Delville et al., 2001; Jolivet et al., 2001; Sobel et al., 2001; Wang et al., 2005). The detrital zircon age distribution of the Jurassic sediments in the Eboliang section (sample E122, Fig. 7D), is very similar to that of the Cenozoic samples, including early to middle Paleozoic zircons (peaks at 422 Ma; 56 \% of total), late Paleozoic to Mesozoic zircons (peaks at ca. $253 \mathrm{Ma} ; 20 \%$ of total) and a few Precambrian zircon (15\% of total). This similarity suggests that the source of the material deposited in the Eboliang region has been largely stable since the early Jurassic including both Permian granitoids and Ordovician to Devonian basement from either or both the Altyn Tagh Range and the Qilian Shan (Figs. 7A and 9).

The Paleogene depocenters of the Qaidam basin were consistently located south of the Eboliang section (see Fig. 12A in Yin et al., 2008b), again excluding material contribution from the Eastern Kunlun Range (Fig. 9A; Meng and Fang, 2008; Yin et al., 2008b; Mao et al., 2014). Paleocurrent directions obtained from conglomerate fabrics (clast imbrications) as well as heavy mineral assemblages suggest that the Paleogene clastic materials deposited in the northwestern Qaidam basin mainly derived from the Qilian Shan to the northeast and the Altyn Tagh Range to the north (Fig. 7; Wu et al., 2011; Fu et al., 2013; Jian et al., 2013). The age spectrum obtained from the three Paleogene samples (E123, EBLE, and E22) are characterized by early to middle Paleozoic zircons (peaks at ca. 414 to ca. $461 \mathrm{Ma} ; 20 \% \sim 43 \%$ of total), late Paleozoic to early Mesozoic zircons (peaks at ca. 246 Ma to ca. 255 Ma; 20 \% $23 \%$ of total), and a progressively increasing proportion of Precambrian zircons 
491

492

493

494

495

496

497

498

499

500

501

502

503

504

505

506

507

508

509

510

511

512

(from $23 \%$ to $37 \%$ ).

The age spectrum of sample E123 displays a distinctive early Neoproterozoic age group (Fig. 7B; 1100 Ma to $850 \mathrm{Ma}$; peak at $911 \mathrm{Ma}$ ). The oscillatory zoning in CL images and the relatively high $\mathrm{Th} / \mathrm{U}$ ratios (over 0.1 , average value 0.3 ) of those early Neoproterozoic zircons in sample E123 indicate a clear magmatic origin (Fig. 10; Hanchar and Rudnick, 1995; Hoskin and Black, 2000; Corfu et al., 2003). As shown in Figure 9A, the early Neoproterozoic sources are few and small in the Altyn Tagh Range and Qilian Shan, but for a large magmatic complex north of the Anxi area. Wang et al. (2013) recently reported a mean zircon U-Pb crystallization age of $~ 910$ Ma for these intrusions, consistent with the 911 Ma peak age in the Paleocene to early Eocene sample E123 (Fig. 9A). The enriched early Neoproterozoic zircon age groups (ca. 1100 to ca. $850 \mathrm{Ma}$ ) in sample E123 that accounts for over 20\% of the total analysis represents a major difference from the age spectrum of the Jurassic and post-Paleocene samples. We suggest that this group indicates that the extensive early Neoprotozoic intrusion north of the Anxi area (Fig. 9A) formed a potential source for the Paleocene to early Eocene strata in the Eboliang section. According to the isopach map of the Paleocene to early Eocene Lulehe Formation provided by Yin et al. (2008b), the main depocenter was located south of the Eboliang section and the strata in the Eboliang section generally thicken southwards and westwards (Fig. 8). In addition, a sub-depocenter developed in the western Qaidam basin close to the early Neoproterozoic basement rocks in the Altyn Tagh Range (see Fig. 12A in Yin et al., 2008b). If the Eboliang section had been continuously situated in roughly the same 
region as it occupies today (Fig. 2), the clastic materials derived from the early Neoproterozoic basement would thus not have been transported to the northwestern Qaidam basin. In addition, the few Neoproterozoic intrusions in the central and northern Qilian Shan region are not only far away from the Eboliang section, but also completely obstructed by the Paleocene uplift of the northern Qaidam thrust belt, clearly revealed by the seismic profiles in the southwestern flank of the Qilian Shan (Yin et al., 2008a). Based on these results combined with the generally south-directed paleoflows reported from the northern Qaidam basin (e.g. Fu et al., 2013; Jian et al., 2013) and the largely accepted hundreds of kilometers of Cenozoic offset along the lithospheric ATF (e.g. Wittlinger et al., 1998; Wang et al., 2006a; Yu et al., 2014; Cheng et al., 2015a, 2015b), we conclude that the Eboliang section must have been located much closer to the present day position of Anxi (Figs. 1 and 2). The single Paleogene zircon age observed in sample EBLE (Fig. 7C) is difficult to interpret since no Cenozoic magmatism has been reported in the Qaidam basin, Altyn Tagh Range or Qilian Shan. Our preferred interpretation is that this 57 Ma zircon was derived from the Cenozoic volcanic ash emitted from the volcanic centers exposed along the northern edge of the Qiangtang Block (e.g. Jolivet et al., 2003; Ding et al., 2007; Staisch et al., 2015).

The post-Oligocene depocenters are all located in the center of the Qaidam basin, south of the Eboliang section (Fig. 8; Meng and Fang, 2008; Yin et al., 2008b; Mao et al., 2014). This again excludes the possibility that the Neogene Eboliang sediments issued from the Eastern Kunlun Range to the south. Consistently, the generally 
south-directed paleocurrents indicate that the sources of the post-Oligocene sediments in the Eboliang section were to the north, probably in the Altyn Tagh Range and the Qilian Shan (Wu et al., 2012b). However, the paleoflows changed from south-directed during the early Miocene, to generally southwest-directed during the Pliocene (Fig. 7). Unidirectional, south-directed paleocurrents prevail during the Quaternary (Fig. 7). Although Miocene to Quaternary strata are still dominated by early to middle Paleozoic zircons (peaks at ca. 444 Ma to ca. 401 Ma; $45 \%$ $48 \%$ of total) and late Paleozoic to Mesozoic zircons (peaks at ca. 258 Ma to ca. 242 Ma; $39 \%$ \% \% of total), Precambrian zircons become scarce (3\% $9 \%$ of total), especially in Pliocene and Quaternary strata (Fig. 7F, 7G and 7H). As shown in the 3D seismic profile (Fig. 11), growth strata that developed during the deposition of the early Miocene series most probably indicate intense tectonic deformation along the adjacent ATF. Based on sediment facies studies and provenance analysis of the Oligocene to Miocene strata in the Xorkol basin, Ritts et al. (2004) concluded that the Oligocene to early Miocene sequence coarsens upwards from low-energy playa and alluvial mudflat deposits to proximal alluvial fan deposits, again supporting early Miocene deformation within the Altyn Tagh Range. A similar transition has been observed in the Oligocene to Miocene strata along the northern flank of the Altyn Tagh Range (Yue et al., 2004a). In addition, Miocene deformation within the Altyn Tagh Range has been clearly registered by thermochronology and paleomagnetism data (e.g. Jolivet et al., 1999; Chen et al., 2001; Jolivet et al., 2001; Wang et al., 2006; Liu et al., 2007; Lu et al., 2014). We thus propose that the disappearance of the Precambrian zircon in the 
post-Oligocene strata is linked to a major change in drainage pattern within the Altyn Tagh Range. The early Miocene deformation along the ATF led to the growth of a prominent topographic barrier, cutting off the link between the Precambrian source rocks in the Altyn Tagh Range and the Eboliang section area. Furthermore, the post-Oligocene samples (EBLN, EB1, ED1 and EE1) were collected in the southern part of the Eboliang fold structure that formed during or after the early Miocene (Figs. 2 and 11 A; e.g. Shang, 2001). Similarly to the material produced in the Altyn Tagh Range, the one sourced from the Qilian Shan was thus blocked east of the elevated growing structure and was not able to reach the deposition area to the south (Figs. 2, 9 and 11A). These results imply that the post-Oligocene clastic material deposited in the northwestern Qaidam basin was mainly derived from restricted local sources and/or recycling of the deformed pre- Oligocene strata.

\subsubsection{Huatugou section}

Along this section the detrital zircons U-Pb ages are again statistically subdivided into three major populations of Precambrian (spanning from ca. $3.2 \mathrm{Ga}$ to $600 \mathrm{Ma}$ ), early to middle Paleozoic (peaks at 460 400 Ma) and late Paleozoic to Mesozoic (peaks at ca. 290 210 Ma) (Fig. 8). The Jurassic to Pleistocene basin depocenters were consistently situated farther southeast of the Huatugou section, which rules out any material contribution from the Qilian Shan to the Huatugou section (Fig. 9A; Meng and Fang, 2008; Yin et al., 2008b; Mao et al., 2014). Late Paleozoic - early Mesozoic granitic intrusions are widespread in the Altyn Tagh and Eastern Kunlun ranges, however, most of the early Mesozoic intrusions 
579

580

581

582

583

584

585

586

587

588

589

590

591

592

593

594

595

596

597

598

599

600

(younger than ca. $260 \mathrm{Ma}$ ) are confined to the Eastern Kunlun Range just south of our sample sites (Fig. 9A). This distinctive pluton distribution, together with the early Neoproterozoic zircons (1100 850 Ma) issued from the remarkably large intrusion in the Altyn Tagh Range (Fig. 9A; Wang et al., 2013; Cheng et al., 2015a) can be used as provenance signatures to identify the source of detrital zircons within our nine sandstone samples.

The poorly sorted, angular grains in the Jurassic samples suggest deposition from a proximal source (see Figs. 5A and 5B in Cheng et al., 2015a). The zircon ages spectrum of the Jurassic sample (CSL3, Fig. 8A) is characterized by an exceptional bimodal distribution (Permian-Triassic and Paleozoic groups). The zircons with ages younger than 260 Ma account for $15.5 \%$ of the total number of analysis, suggesting that the Eastern Kunlun Range was a significant source of material for the Jurassic strata in the Huatugou section. This result is consistent with the general north- to west- directed paleoflows (Fig. 8A). The few Precambrian zircons (no early Neoproterozoic zircons) as well as the few south-directed paleocurrents might indicate limited contribution from the Altyn Tagh Range to the north, which suggests a limited topographic relief within that range, locally exposing basement rocks (Delville et al., 2001; Sobel et al., 2001; Ritts and Biffi, 2000).

In the Paleocene-early Eocene sample (S23) and the middle Eocene sample (HTG-E), the age spectrums are still largely bimodal, with about $15 \%$ of $<260$ Ma zircons, suggesting that the Eastern Kunlun Range was still a significant source for these samples. This assumption is consistent with the N-NE-directed paleoflows 
601

602

603

604

605

606

607

608

609

610

611

612

613

614

615

616

617

618

619

620

621

622

observed in the Paleocene to middle Eocene series (Fig. 8B and 8C; Meng and Fang, 2008; Fu et al., 2013; Li et al., 2015). On the other hand, the increasing proportion of Precambrian zircons (over 3\% of early Neoproterozoic zircons in both samples) indicates that the Altyn Tagh Range was gradually becoming a significant source of clastic material for the Paleocene to middle Eocene strata in the Huatugou section.

The late Eocene to Oligocene sample (QX1-2) displays a significant change in the detrital zircon age distribution pattern (Fig. 8C, 8D and 8E): the major Mesozoic age peak observed in the previous samples becomes nearly negligible with the proportion of $<260$ Ma zircons decreasing dramatically (from 13.6\% in sample S23 and 18.4\% in sample HTG-E to 3.1\% in sample QX1-2). In addition, the paleocurrent directions changed abruptly from generally north-directed in the Paleocene to middle Eocene strata to south-directed in the late Eocene strata (Fig. 8C and 8D). This implies a major shift in the source region from the Eastern Kunlun Range to the Altyn Tagh Range during the middle to late Eocene time. The proportion of early Neoproterozoic zircons gradually increased (e.g. from $3.1 \%$ in sample HTG-E to $5.1 \%$ in sample QX1-2) further attesting that basement rocks in the Altyn Tagh Range served as a significant source for the sediments in the Huatugou section.

Recent sedimentology and paleomagnetic studies demonstrated that the relatively rigid Qaidam basin, together with the western segment of the Eastern Kunlun Range, have been transported northeastward along the ATF during the Cenozoic (Wang et al., 2006a; Yu et al., 2014; Cheng et al., 2015a, 2015b). This displacement occurred without obvious basin-scale vertical axis rotation with respect to the Eurasia Plate 
623

624

625

since the early Eocene (Dupont-Nivet et al., 2002; Yu et al., 2014). We suggest that this sharp change in the detrital zircon age distribution pattern was directly related to the onset of large-scale left-lateral strike-slip displacement along the ATF. Except for the still slightly increasing proportion of Precambrian ages, the detrital zircon U-Pb age distribution registered in the Oligocene sample (QX1-1) is similar to that in the late Eocene sample (QX1-2), suggesting a relatively stable drainage pattern from the late Eocene to the Oligocene (Fig. 8D and 8E).

The age spectrum of the early Miocene sample (HTG-N) is again characterized by a major Paleozoic age peak and a minor Mesozoic age sub-peak (Fig. 8F). However, the amount of Precambrian zircons decreased significantly (early Neoproterozoic ages only represent $1.1 \%$ of the total analysis). A similar decrease in the proportion of Precambrian zircons was also registered in the early Miocene sample of the Eboliang section (sample EBLN in Fig. 7E), indicating a regional change in the source area and/or drainage pattern throughout the Altyn Tagh Range. As already mentioned in the provenance analysis of samples from the Eboliang section, we suggest that the regional early Miocene deformation within the Altyn Tagh Range cut off the link between the Precambrian source rocks in the Altyn Tagh and Qilian Shan ranges and the depositional area in the Huatugou and Eboliang sections. The early Miocene clastic material in these two sections was mainly derived from more restricted local source regions and recycling of the deformed Paleocene to Oligocene strata.

Detrital zircon age distributions in the middle Miocene to Pleistocene samples 
645

646

647

648

649

650

651

652

653

654

655

656

657

658

659

660

661

662

663

664

665

666

(CSL4, SZG1 and CSL5) are similar, characterized by a major middle Paleozoic age peak, a minor but consistent Mesozoic age peak as well as few Precambrian zircons (Fig. 8G, 8H and 8I). Based on seismic profile interpretation, the fold structures developing perpendicular to the Altyn Tagh fault trend (e.g. the Yingxiongling structure, Fig. 2) initiated during or after the Oligocene (Yin et al., 2007; Yin et al., 2008a; Wu et al., 2014). After the Oligocene onset of deformation, the Huatugou section, located in the northernmost part of the prominent Yingxiongling uplift structure, was gradually isolated from the main Qaidam basin. A complex, local drainage pattern developed while recycling of the deformed Paleocene to Oligocene strata served as a major material source (Fig. 8).

\subsection{Tectonics implications}

6.3.1 Source to sink relation between the Qaidam basin and the Altyn Tagh Range Provenance analysis results obtained from the two studied sections along the ATF reveal that the source to sink relation between the Qaidam basin and the Altyn Tagh Range underwent a three stages evolution:

During the Paleocene and early Eocene, the Eboliang and Huatugou sections were respectively located near the present day position of Anxi and Tula (Figs. 2A and 12A). The basement rocks in the Altyn Tagh Range (including the early Neoproterozoic intrusion north of the Anxi area) served as the major source area for the Eboliang section while a part of the material deposited in the Huatugou section derived from the Eastern Kunlun Range.

By early to middle Eocene, left-lateral strike-slip movement along the ATF 
667

668 (including the Eboliang and Huatugou sections). This migration ultimately

669 disconnected the Eboliang section from the early Neoproterozoic source north of the

670

671

672

673

674

675

676

677

678

679

680

681

682

683

684

685

686

687

688

initiated, resulting in gradually northeastward migration of the Qaidam basin Anxi area (Fig Anxi area (Fig. 12B), as attested by the decreasing proportion of early Neoprotozoic zircons (from $19.4 \%$ in Paleocene to early Eocene sample E123, to $5.3 \%$ in middle-late Eocene sample EBLE and 3.6\% in the Oligocene sample E22). Similarly, the Huatugou section gradually moved away from the Tula area towards Anxi (Fig. 12B). This led to a decreasing proportion of $<260$ Ma zircons (from ca. $15 \%$ in the Paleocene to middle Eocene samples S23 and HTG-E to ca. 3\% in the late Eocene sample QX1-2; Fig. 8B, 8C and 8D) and to an abrupt change in paleocurrent directions (Fig. 8C and 8D). In parallel, the gradual increase in early Neoproterozoic zircons (from ca. 3\% in middle Eocene sample HTG-E to 6.5\% in Oligocene sample QX1-1; Fig. 8C, 8D and 8E) suggests that the Huatugou section might be close to the early Neoproterozoic intrusives north of the Anxi area during the middle Eocene to Oligocene.

On seimic profiles BB' and CC' (trending perpendicular to the Altyn Tagh Range; Figs. 2, 11A and 11B), several basement-involved thrust faults offset the Mesozoic strata and die out in the Eocene and Oligocene strata. In addition, the Eocene to Oligocene strata slightly thicken towards the depocenter exhibiting a growth-strata structure (Fig. 11B). The oldest unit affected by growth strata is the middle Eocene lower Xiaganchaigou Fm., suggesting that the deformation along the ATF initiated around that time. Paleocurrents measurements and provenance analysis of 
689

690

691

692

693

694

695

696

697

698

699

700

701

702

703

704

705

706

707

708

709

710

conglomerates in the Xorkol basin (Fig. 2) and western Qaidam basin indicate that

uplift along the central segment of the ATF occurred prior to the Oligocene (Yue et al., 2001; Ritts et al., 2004; Wu et al., 2012a, 2012b), probably during the early to middle Eocene.

Since the early Miocene, the Eboliang and Huatugou sections continuously migrated northeastwards along the left-lateral strike-slip ATF. However, the scarcity of the Precambrain zircons, especially the early Neoproterozoic zircons, in the post-Oligocene sediments (e.g. sample EBLN in the Eboliang section and sample HTG-N in the Huatugou section) indicates a major change in the drainage pattern leading to disruption of the source to sink relation between the Altyn Tagh Range and the western Qaidam basin. On seimic profiles BB' and CC' (Fig. 11A and 11B), generally northward-tapering growth strata within the Miocene to Pliocene deposits are well-developed, likely associated with the left-lateral faulting along the ATF and deformation within the Altyn Tagh Range since the early Miocene. The postOligocene deformation and uplift within the Altyn Tagh Range and northwestern Qaidam basin largely modified the regional drainage pattern. Most of the material derived from the erosion of the Altyn Tagh Range was directed towards the Tarim basin to the north (Fig. 12C; Yue et al., 2004b). The post-Oligocene clastic materials deposited in the western Qaidam basin was derived from local sources including recycling of the deformed Paleocene to Oligocene strata.

\subsubsection{Implications for the Miocene deformation within the Altyn Tagh Range}

In this study, the disappearance of an early Neoprotozoic component in the 
detrital zircon age spectra of the Miocene strata both in the Eboliang and Huatugou sections as well as the Miocene initiation of growth strata within the northwestern Qaidam basin are indicative of enhanced tectonic activity within the Altyn Tagh Range and Qaidam basin since the Miocene. This finding is consistent with the results of several previous multi-faceted studies including: thermochronology on the basement rocks within the Altyn Tagh Range (e.g. Chen et al., 2001; Jolivet et al., 1999, 2001; Sobel et al., 2001; Zhang et al., 2012); paleomagnetism studies on the Cenozoic strata within the northwestern Qaidam basin (e.g. Zhang et al., 2013b; Lu et al., 2014; Chang et al., 2015); basin-scale seismic profile interpretation (Meng and Fang, 2008; Yin et al., 2008a, 2008b; Wang et al., 2010; Cheng et al., 2015a); provenance analyses along the Altyn Tagh Range (e.g. Yue et al., 2001; Yin et al., 2002; Wu et al., 2012a, 2012b) and synthetized tectonic analysis (e.g. Burchfiel et al.,1989; Meyer et al., 1998; Fu et al., 2015). In addition, the Miocene deformation phase has been widely recognized in the northern and eastern Tibetan plateau, including the Eastern Kunlun Range, the Altyn Tagh Range, the Longmen Shan and the Qilian Shan (e.g., Kirby et al., 2002; Clark et al., 2004; Ding et al., 2004; Ritts et al., 2004; Sun et al., 2005; Duvall et al., 2013; Yuan et al., 2013; Cheng et al., 2014, 2015a, 2016; Lease, 2014; Chang et al., 2015; Jolivet et al., 2015), which may reflect a critical period in the growth process of the Tibetan plateau.

\subsubsection{Implications for the Cenozoic offset of the ATF}

The Eboliang and Huatugou sections record the northward migration of the Qaidam basin and can be used as two piercing points for defining the Cenozoic offset 
of the ATF. In addition, the early Neoproterozoic intrusion in the Altyn Tagh Range strikes NEE-SWW along the Altyn Tagh fault, and has an elongation of ca. $80 \mathrm{~km}$. The Eboliang section is located south of this $80 \mathrm{~km}$ wide early Neoproterozoic intrusion and separated from the intrusion by the ATF. Considering the actual $360 \mathrm{~km}$ gap between the center of this early Neoproterozoic intrusion and the Eboliang section, an average of $360 \pm 40 \mathrm{~km}$ offset on the Altyn Tagh fault can be estimated. A similar $\sim 360 \mathrm{~km}$ offset is obtained by corelating the Huatugou section to the Mesozoic plutons south of the Tula area. We concede that, from analyzing detrital zircon spectra of Mesozoic to Cenozoic strata, the Eboliang-Anxi piercing point is much more convincing than the Tula-Huatugou piercing point. However, by correlating the lithology and sedimentary features of the Cenozoic strata and analyzing the detrital zircon $\mathrm{U}-\mathrm{Pb}$ ages from Mesozoic strata in both the Tula and Huatugou sections, we previously found potential links between both sections (Cheng et al., 2015a). We thus considered that the Tula section used to be a part of the Qaidam basin and was left behind due to the northeastward migration of the Qaidam basin. Two faults which have been indentified by previous research (Figs. 1, 2 and 12; e.g. Cowgill, et al., 2003) are acting as boundaries between the detached Qaidam basin and the relic Tula sub-basin (Cheng et al., 2015a). Since the early Eocene, faulting on the ATF induced these NE-SW-trending branch faults, now covered by Quaternary deposits. Northwards migration of the rigid Qaidam basin left the Tula section and parts of the Kunlun basement behind (Cheng et al., 2015a). Moreover, considering the strong mechanical behaviour of the rigid Qaidam basin, the Huatugou section should be 
approximately located near the present-day position of the Tula section if we restore the horizontal offset along the AFT based on the convincing Eboliang-Anxi piercing point. Consequently, we suggest a $360 \pm 40 \mathrm{~km}$ offset along the ATF, which contradicts the extraordinary $~ 1200 \mathrm{~km}$ offset estimation (CSBS, 1992), but is in excellent agreement with independent, albeit indirect piercing points suggesting 300 to $400 \mathrm{~km}$ of displacement along the Altyn Tagh Range: (1) $400 \pm 60 \mathrm{~km}$ offset based on Jurassic lacustrine shorelines along the northern and southern sides of the Altyn Tagh fault (Ritts and Biffi, 2000), (2) 375 km offset of the Cambrian magmatic arc in the Qilian Shan and the Altyn Tagh Range (Gehrels et al., 2003a), (3) 375 $\pm 25 \mathrm{~km}$ offset of pre-Oligocene strata between the Qaidam and Xorkol basins (Yue et al., 2001), (4) 360 $\pm 40 \mathrm{~km}$ offset estimation based on source to sink relation between the Xorkol basin and the North Qilian Shan (Yue et al., 2005), (5) 350 400 km offset based on eclogite, ophiolite and blueschist facies units in the Altyn Tagh Range and Qilian Shan (Yang et al., 2001; Zhang et al., 2001), (6) 350 km offset based on similar early to middle Jurassic cooling zones on both side of the Altyn Tagh fault (Sobel et al., 2001). This large-scale lithospheric offset along the ATF would be totally accomodated by crustal deformation within the terrane to the east, especially by the NE-SW shortening and eastward extrusion along the faults within the Qilian Shan (e.g. Yin et al., 2002, 2008a; Cheng et al., 2015b). The confirmation of the hundreds of kilometers of displacement along the strike-slip ATF again supports the eastward extrusion of the Tibetan plateau driven by the India-Asia collision. 


\section{Conclusion}

Detrital zircon U-Pb age patterns evolution from two Jurassic to Pleistocene stratigraphic sections in the northwestern Qaidam basin associated to high-quality seismic-reflection profiles revealed that:

1. During the Paleocene to early Eocene, the Eboliang and Huatugou sections were respectively located near the present-day position of the Anxi and Tula areas. The basement rocks in the Altyn Tagh Range served as the significant source for the sediments to the Eboliang section, while the material deposited in the Huatugou section mostly derived from the Eastern Kunlun Range.

2. Left-lateral strike-slip movement along the ATF initiated during the early-middle Eocene, resulting in gradual northeastward migration of the Qaidam basin.

3. The post-Oligocene deformation within the Altyn Tagh Range and northwestern Qaidam basin strongly modified the regional drainage pattern. By Oligocene times, most of the material issued from the erosion of the Altyn Tagh Range was directed towards the Tarim basin to the north. The post-Oligocene clastic materials in the western Qaidam basin was mainly derived from local sources largely including recycling of the deformed Paleocene to Oligocene strata.

4. Using the Eboliang and Huatugou sections as piercing points, we estimate a $360 \pm 40 \mathrm{~km}$ offset along the ATF. 


\section{Acknowledgements}

800

801

802

803

804

805

806

807

808

809

810

811

812

813

814

815

816

817

This work was supported by the Oil and Gas Scientific and Technologic Major Programs of China (Grant ZX05003) and the China Scholarship Council - Campus France Egide Cai Yuanpei program (201404490136; N 32393WL (2014)). We gratefully acknowledge the assistance of Shuwei Guan, Qinyang Meng, Ruiying Chen, Chuanmin Zhou, Suping Zhou, Xiangjiang Yu, Xiang Cheng, Wei Du, Runchao Liu and Tuo Zhang during field work. We thank Li Su of the Geological Lab Center, China University of Geosciences (Beijing), for her help during detrital zircon analysis and to Chaodong Wu, Chuanwu Wang, Yan Chen for their helpful suggestions on the Cenozoic evolution of the Qaidam basin. Communications with Michel Ballevre, Sylvie Bourquin, Hervé Régnauld, Baofu Han and Zhicheng Zhang have sharpened the discussion on the appropriate piercing points. We particularly thank Science Editor Jean-Philippe Avouac and two anonymous reviewers for their careful and insightful comments. We gratefully acknowledge the journal manager, Iswarya Samikannu, for handling our manuscript.

\section{Support Information}

Appendix A. U-Pb analysis of detrital zircons from the 11 sandstone samples.

Appendix B. Detailed description of the U-Pb geochronology results. 


\section{References}

819

820

821

822

823

824

825

826

827

828

829

830

831

832

833

834

835

836

837

838

839

Andersen, T., 2002. Correction of common lead in U-Pb analyses that do not report ${ }^{204} \mathrm{~Pb}$. Chemical Geology 192, 59-79.

Arnaud, N., Tapponnier, P., Roger, F., Brunel, M., Scharer, U., Chen, W., Xu, Z., 2003.

Evidence for Mesozoic shear along the western Kunlun and Altyn-Tagh fault, northern Tibet (China). Journal of Geophysical Research: Solid Earth (1978-2012) 108.

Avouac, J.P., Tapponnier, P., 1993. Kinematic model of active deformation in central Asia. Geophysical Research Letters 20, 895-898.

Black, L.P., Kamo, S.L., Allen, C.M., Aleinikoff, J.N., Davis, D.W., Korsch, R.J., Foudoulis, C., 2003. TEMORA 1: a new zircon standard for Phanerozoic U-Pb geochronology. Chemical Geology 200, 155-170.

Bovet, P.M., Ritts, B.D., Gehrels, G., Abbink, A.O., Darby, B., Hourigan, J., 2009.

Evidence of Miocene crustal shortening in the north Qilian Shan from Cenozoic stratigraphy of the western Hexi Corridor, Gansu Province, China. American Journal of Science 309, 290-329.

Braitenberg, C., Wang, Y., Fang, J., Hsu, H., 2003. Spatial variations of flexure parameters over the Tibet-Quinghai plateau. Earth and Planetary Science Letters 205, 211-224.

Burchfiel, B.C., Quidong, D., Molnar, P., Royden, L., Yipeng, W., Peizhen, Z., Weiqi, Z., 1989. Intracrustal detachment within zones of continental deformation. Geology 17, 748-752. 
840

841

842

Chang, H., Li, L., Qiang, X., Garzione, C.N., Pullen, A., An, Z., 2015. Magnetostratigraphy of Cenozoic deposits in the western Qaidam Basin and its implication for the surface uplift of the northeastern margin of the Tibetan Plateau. Earth and Planetary Science Letters 430, 271-283.

Chen, Z.L., Zhang, Y.Q., Wang, X.F., Chen, X.H., 2001. Fission Track Dating of Apatite Constrains on the Cenozoic Uplift of the Altyn Tagh Mountain. Acta Geoscientia Sinica 22, 413-418 (in Chinese with English abstract).

Chen, X.H., Wang, X.F., E. George, G., Yang, Y., Qin, H., Chen, Z.L., Yang, F., Chen, B.L., Li, X.Z., 2004. Early Paleozoic Magmatism and Gold Mineralization in the Northern Altun, NW China. Acta Geologica Sinica-English Edition 78, 515-523.

Chen, X., Gehrels, G., Yin, A., Zhou, Q., Huang, P., 2015. Geochemical and $\mathrm{Nd}-\mathrm{Sr}-\mathrm{Pb}-\mathrm{O}$ isotopic constrains on Permo-Triassic magmatism in eastern Qaidam Basin, northern Qinghai-Tibetan plateau: Implications for the evolution of the Paleo-Tethys. Journal of Asian Earth Sciences 114, Part 4, 674-692.

Chen, Y., Gilder, S., Halim, N., Cogné, J.P., Courtillot, V., 2002. New paleomagnetic constraints on central Asian kinematics: Displacement along the Altyn Tagh fault and rotation of the Qaidam Basin. Tectonics 21, 1042.

Cheng, F., Jolivet, M., Fu, S., Zhang, Q., Guan, S., Yu, X., Guo, Z., 2014. Northward growth of the Qimen Tagh Range: A new model accounting for the Late Neogene strike-slip deformation of the SW Qaidam Basin. Tectonophysics 632, 32-47.

Cheng, F., Guo, Z., Jenkins, H.S., Fu, S., Cheng, X., 2015a. Initial rupture and displacement on the Altyn Tagh fault, northern Tibetan Plateau: Constraints based on 
862

863

864

865

866

867

868

869

870

871

872

873

874

875

876

877

878

879

880

881

882

883

residual Mesozoic to Cenozoic strata in the western Qaidam Basin. Geosphere 11, 921-942.

Cheng, F., Jolivet, M., Dupont-Nivet, G., Wang, L., Yu, X., Guo, Z., 2015b. Lateral extrusion along the Altyn Tagh Fault, Qilian Shan (NE Tibet): insight from a 3D crustal budget. Terra Nova 27, 416-425.

Cheng, F., Fu, S., Jolivet, M., Zhang, C., Guo, Z., 2016. Source to sink relation between the Eastern Kunlun Range and the Qaidam Basin, northern Tibetan Plateau, during the Cenozoic. Geological Society of America Bulletin 128, 258-283.

Clark, M., Schoenbohm, L., Royden, L., Whipple, K., Burchfiel, B., Zhang, X., Tang, W., Wang, E., Chen, L., 2004. Surface uplift, tectonics, and erosion of eastern Tibet from large-scale drainage patterns. Tectonics 23, TC1006.

Corfu, F., Hanchar, J.M., Hoskin, P.W., Kinny, P., 2003. Atlas of zircon textures. Reviews in mineralogy and geochemistry 53, 469-500.

Cowgill, E., Yin, A., Harrison, T.M., Xiao-Feng, W., 2003. Reconstruction of the Altyn Tagh fault based on U-Pb geochronology: Role of back thrusts, mantle sutures, and heterogeneous crustal strength in forming the Tibetan Plateau. Journal of Geophysical Research 108, 2346.

CSBS (Chinese Stata Bureau of Seismology), 1992. The Altyn Tagh Active Fault System. Seismology Publishing House, Beijing, pp. 1-319 (in Chinese).

Dai, J., Wang, C., Hourigan, J., Santosh, M., 2013. Multi-stage tectono-magmatic events of the Eastern Kunlun Range, northern Tibet: Insights from U-Pb geochronology and (U-Th)/He thermochronology. Tectonophysics 599, 97-106. 
884

885

886

887

888

889

890

891

892

893

894

895

896

897

898

899

900

901

902

903

904

905

Darby, B.J., Ritts, B.D., Yue, Y., Meng, Q., 2005. Did the Altyn Tagh fault extend beyond the Tibetan Plateau? Earth and Planetary Science Letters 240, 425-435.

Delville, N., Arnaud, N., Montel, J.-M., Roger, F., Brunel, M., Tapponnier, P., Sobel, E., 2001. Paleozoic to Cenozoic deformation along the Altyn Tagh fault in the Altun Shan massif area, eastern Qilian Shan, northeastern Tibet, China. Geological Society of America Memoirs 194, 269-292.

Deng, T., Wang, X.M., 2004a. New material of the Neogene rhinocerotids from the Qaidam Basin in Qinghai, China. Vert. PalAsiat. 42, 216-229.

Deng, T., Wang, X.M., 2004b. Late Miocene Hipparion (Equidae, Mammalia) of eastern Qaidam Basin in Qinghai, China. Vert. PalAsiat. 42, 316-333.

Ding, G., Chen, J., Tian, Q., Shen, X., Xing, C., Wei, K., 2004. Active faults and magnitudes of left-lateral displacement along the northern margin of the Tibetan Plateau. Tectonophysics 380, 243-260.

Ding, L., Kapp, P., Yue, Y., Lai, Q., 2007. Postcollisional calc-alkaline lavas and xenoliths from the southern Qiangtang terrane, central Tibet. Earth and Planetary Science Letters 254, 28-38.

Dong, Z., Pei, X., Gu, P., Zhang, H., Chen, R., Zhang, X., 2014. Geochronology, Geochemistry, and Hf Isoplot of Yanchangbeishan Granodiorite of Lenghu Area in Qinghai. Nonwestern Geology 47 (4), 141-155 (in Chinese with English abstract).

Dong, Z., Gu, P., Chen, R., Zhang, X., Zhang, H., 2015. Geochronology, Geochemistry, and Hf Isoplot of Yanchangbeishan Adamellite of Lenghu Area in Qinghai. Earth Science-Journal of China University of Geosciences 40, 130-144 (in 
Chinese with English abstract).

Duvall, A.R., Clark, M.K., Kirby, E., Farley, K.A., Craddock, W.H., Li, C., Yuan, D.-Y., 2013. Low-temperature thermochronometry along the Kunlun and Haiyuan Faults, NE Tibetan Plateau: Evidence for kinematic change during late-stage orogenesis. Tectonics 32, 1190-1211.

Dupont-Nivet, G., Butler, R.F., Yin, A., Chen, X., 2002. Paleomagnetism indicates no Neogene rotation of the Qaidam Basin in northern Tibet during Indo-Asian collision. Geology 30, 263.

Dupont-Nivet, G., Lippert, P.C., Van Hinsbergen, D.J.J., Meijers, M.J.M., Kapp, P., 2010. Palaeolatitude and age of the Indo-Asia collision: palaeomagnetic constraints. Geophysical Journal International 182, 1189-1198.

England, P., Houseman, G., 1989. Extension during continental convergence, with application to the Tibetan Plateau. Journal of Geophysical Research: Solid Earth (1978-2012) 94, 17561-17579.

Fang, X., Zhang, W., Meng, Q., Gao, J., Wang, X., King, J., Song, C., Dai, S., Miao, Y., 2007. High-resolution magnetostratigraphy of the Neogene Huaitoutala section in the eastern Qaidam Basin on the NE Tibetan Plateau, Qinghai Province, China and its implication on tectonic uplift of the NE Tibetan Plateau. Earth and Planetary Science Letters 258, 293-306.

Fedo, C.M., Sircombe, K.N., Rainbird, R.H., 2003. Detrital zircon analysis of the sedimentary record. Reviews in mineralogy and geochemistry 53, 277-303.

Fu, L., Guan, P., Zhao, W. Y., Wang, M., Zhang, Y., Lu, J. W., 2013. Heavy mineral 
928

929

930

931

932

933

934

feature and provenance analysis of Paleogene Lulehe Formation in Qaidam Basin. Acta Petrologica Sinica 29, 2867-2875 (in Chinese with English abstract).

Fu, S., Ma, D., Guo, Z., Cheng, F., 2015. Strike-slip superimposed Qaidam Basin and its control on oil and gas accumulation, NW China, Petroleum Exploration and Development 42, 779-789.

Gao, J., Li, S., Dai, S., Li, A., Peng, Y., 2009. Constraints of tectonic evolution in provenance from detrital zircon fission-track data of Cenozoic strata of Xichagou district in western Qaidam basin. Journal of Lanzhou University (Natural Sciences) 45, 1-7 (in Chinese with English abstract).

Gehrels, G.E., Yin, A., Wang, X.F., 2003a. Magmatic history of the northeastern Tibetan Plateau. Journal of Geophysical Research 108, 2423.

Gehrels, G.E., Yin, A., Wang, X.F., 2003b. Detrital-zircon geochronology of the northeastern Tibetan plateau. Geological Society of America Bulletin 115, 881-896.

Gehrels, G., Kapp, P., DeCelles, P., Pullen, A., Blakey, R., Weislogel, A., Ding, L., Guynn, J., Martin, A., McQuarrie, N., 2011. Detrital zircon geochronology of pre-Tertiary strata in the Tibetan-Himalayan orogen. Tectonics 30, TC5016.

Gehrels, G., 2014. Detrital Zircon U-Pb Geochronology Applied to Tectonics. Annual Review of Earth and Planetary Sciences 42, 127-149.

Guo, J.J., Li, H.K., 1999. Angular Unconformity between the Huashishan Group and Huangzhong Group in the Eastern Mid-Qilian Massif: Identification and Implications. Progress in Precambrian Research 22, 47-52.

Hanchar, J., Rudnick, R., 1995. Revealing hidden structures: the application of 
950 951 lower crustal xenoliths. Lithos 36, 289-303.

952 Hoskin, P., Black, L., 2000. Metamorphic zircon formation by solid-state 953

954

955

956

957

958

959

960

961

962

963

964

965

966

967

968

969

970

971

cathodoluminescence and back-scattered electron imaging to dating zircons from recrystallization of protolith igneous zircon. Journal of metamorphic Geology 18, 423-439.

Heermance, R.V., Pullen, A., Kapp, P., Garzione, C.N., Bogue, S., Ding, L., Song, P., 2013. Climatic and tectonic controls on sedimentation and erosion during the Pliocene-Quaternary in the Qaidam Basin (China). Geological Society of America Bulletin 125, 833-856.

Huang, H., Huang, Q., Ma, Y., 1996. Geology of Qaidam Basin and its Petroleum Prediction. Geological Publishing House, Beijing, pp. 1-257 (in Chinese with English abstract).

HGSI (Hunan Geological Survey Institute), 2003. The Report of Regional Geological Survey of Qiemo at Scale 1:250,000. China Industry Press, Beijing, pp. 1-281 in Chinese with English abstract).

Huo, G.M., 1990. Petroleum Geology of China: Oil Fields in Qianghai and Xizang, 14. Chinese Petroleum Industry Press, Beijing, pp. 1-483 (in Chinese with English abstract).

IGSQP (Institute of Geological Survey of Qinhai Province), 2004. The Report of Regional Geological Survey at Scale 1:250000. P.R.C. China Industry Press, Beijing, pp. 1-386 (in Chinese).

Jian, X., Guan, P., Zhang, D.W., Zhang, W., Feng, F., Liu, R.J., Lin, S.D., 2013. 
972

973

974

975

976

977

978

979

980

981

982

983

984

985

986

987

988

989

990

991

992

993

Provenance of Tertiary sandstone in the northern Qaidam basin, northeastern Tibetan Plateau: Integration of framework petrography, heavy mineral analysis and mineral chemistry. Sedimentary Geology 290, 109-125.

Jolivet, M., Roger, F., Arnaud, N., Brunel, M., Tapponnier, P., Seward, D., 1999. Histoire de l'exhumation de l'Altun Shan: indications sur l'âge de la subduction du bloc du Tarim sous le système de l'Altyn Tagh (Nord Tibet). Comptes Rendus de l'Académie des Sciences-Series IIA-Earth and Planetary Science 329, 749-755.

Jolivet, M., Brunel, M., Seward, D., Xu, Z., Yang, J., Roger, F., Tapponnier, P., Malavieille, J., Arnaud, N., Wu, C., 2001. Mesozoic and Cenozoic tectonics of the northern edge of the Tibetan plateau: fission-track constraints. Tectonophysics 343, $111-134$.

Jolivet, M., Brunel, M., Seward, D., Xu, Z., Yang, J., Malavieille, J., Roger, F., Leyreloup, A., Arnaud, N., Wu, C., 2003. Neogene extension and volcanism in the Kunlun Fault Zone, northern Tibet: New constraints on the age of the Kunlun Fault. Tectonics 22, 1052.

Jolivet, M., Roger, F., Xu, Z.Q., Paquette, J.L., Cao, H., 2015. Mesozoic-Cenozoic evolution of the Danba dome (Songpan Garzê, East Tibet) as inferred from LA-ICPMS U-Pb and fission-track data. Journal of Asian Earth Sciences 102, 180-204.

Ke, X., Ji, J., Zhang, K., Kou, X., Song, B., Wang, C., 2013. Magnetostratigraphy and Anisotropy of Magnetic Susceptibility of the Lulehe Formation in the Northeastern Qaidam Basin. Acta Geologica Sinica-English Edition 87, 576-587. 
Kirby, E., Reiners, P.W., Krol, M.A., Whipple, K.X., Hodges, K.V., Farley, K.A., Tang, W.Q., Chen, Z.L., 2002. Late Cenozoic evolution of the eastern margin of the Tibetan Plateau: Inferences from ${ }^{40} \mathrm{Ar} /{ }^{39} \mathrm{Ar}$ and (U-Th)/He thermochronology. Tectonics 21, 1001.

Lease, R.O., 2014. Cenozoic mountain building on the northeastern Tibetan Plateau. Geological Society of America Special Papers 507, 115-127.

Li, H.B., Yang, J.S., Xu, Z.Q., Sun, Z.M., Tapponnier, P., van der Woerd, J., Meriaux, A.-S., 2006. The constraint of the Altyn Tagh fault system to the growth and rise of the northern Tibetan Plateau. Earth Science Frontiers 13, 59-79 (in Chinese with English abstract).

Li, W., Neubauer, F., Liu, Y.J., Genser, J., Ren, S.M., Han, G.Q., Liang, C.Y., 2013. Paleozoic evolution of the Qimantagh magmatic arcs, Eastern Kunlun Mountains: constraints from zircon dating of granitoids and modern river sands. Journal of Asian Earth Sciences 77, 183-202.

Li, L., Guo, Z., Guan, S., Zhou, S., Wang, M., Fang, Y., Zhang, C., 2015. Heavy mineral assemblage characteristics and the Cenozoic paleogeographic evolution in southwestern Qaidam Basin. Science China Earth Sciences 58, 859-875.

Liu, Y. H., Mo, X. X., Yu, X. H., Zhang, X. T. and Xu, G. W., 2006. Zircon SHRIMP $\mathrm{U}-\mathrm{Pb}$ dating of the Jingren granite, Yemaquan region of the east Kunlun and its geological significance: Acta Petrologica Sinica 22, 2457-2463 (in Chinese with English abstract).

Liu, Y.J., Neubauer, F., Genser, J., Ge, X.H., Takasu, A., Yuan, S.H., Chang, L.H., Li, 
W.M., 2007. Geochronology of the initiation and displacement of the Altyn Strike-Slip Fault, western China. Journal of Asian Earth Sciences 29, 243-252.

Liu, D., Jolivet, M., Yang, W., Zhang, Z., Cheng, F., Zhu, B., Guo, Z., 2013. Latest Paleozoic-Early Mesozoic basin-range interactions in South Tian Shan (northwest China) and their tectonic significance: Constraints from detrital zircon $\mathrm{U}-\mathrm{Pb}$ ages. Tectonophysics 599, 197-213.

Liu, D., Cheng, F., Guo, Z., Jolivet, M., Song, Y., 2015. Lahar facies of the Latest Paleozoic Arbasay Formation: Geomorphological characters and paleoenvironment reconstruction of Northern Tian Shan, NW China. Journal of Asian Earth Sciences 113, Part 1, 282-292.

Long, X., Yuan, C., Sun, M., Kröner, A., Zhao, G., 2014. New geochemical and combined zircon $\mathrm{U}-\mathrm{Pb}$ and $\mathrm{Lu}-\mathrm{Hf}$ isotopic data of orthogneisses in the northern Altyn Tagh, northern margin of the Tibetan plateau: Implication for Archean evolution of the Dunhuang Block and crust formation in NW China. Lithos 200-201, 418-431.

Lu, S.N., 2002. Preliminary Study of Precambrian Geology in the North Tibet-Qinghai Plateau. Geological Publishing House, Beijing, pp. 1-125 (in Chinese). Lu, S.N., Yuan, G.B., 2003. Geochronology of early Precambrian magmatic activities in Aketasdhtage, East Altyn Tagh. Acta Geological Sinica 77, $61-68$ (in Chinese with English abstract).

Lu, S.N., Li, H.K., Zhang, C.L., Niu, G.H., 2008. Geological and geochronological evidence for the Precambrian evolution of the Tarim Craton and surrounding continental fragments. Precambrian Research 160, 94-107. 
Lu, H., Xiong, S., 2009. Magnetostratigraphy of the Dahonggou section, northern Qaidam Basin and its bearing on Cenozoic tectonic evolution of the Qilian Shan and Altyn Tagh Fault. Earth and Planetary Science Letters 288, 539-550.

Lu, H., Wang, E., Meng, K., 2014. Paleomagnetism and anisotropy of magnetic susceptibility of the Tertiary Janggalsay section (southeast Tarim basin): Implications for Miocene tectonic evolution of the Altyn Tagh Range. Tectonophysics 618, 67-78.

Ludwig, K.R., 2003. User's manual for Isoplot 3.0: a geochronological toolkit for Microsoft Excel. Berkeley Geochronology Center. Spec. Pub., 4, pp. 1-71.

Mao, L.G., Xiao, A.C., Wu, L., Li, B.L., Wang, L.Q., Lou, Q.Q., Dong, Y.P., Qin, S.H., 2014. Cenozoic tectonic and sedimentary evolution of southern Qaidam Basin, NE Tibetan Plateau and its implication for the rejuvenation of Eastern Kunlun Mountains. Science China Earth Sciences, 1-14 (in Chinese).

Meng, Q.R., Hu, J.M., Yang, F.Z., 2001. Timing and magnitude of displacement on the Altyn Tagh fault: constraints from stratigraphic correlation of adjoining Tarim and Qaidam basins, NW China. Terra Nova 13, 86-91.

Meng, Q.R., Fang, X., 2008. Cenozoic tectonic development of the Qaidam Basin in the northeastern Tibetan Plateau. Geological Society of America Special Papers 444, $1-24$.

Métivier, F., Gaudemer, Y., Tapponnier, P., Meyer, B., 1998. Northeastward growth of the Tibet plateau deduced from balanced reconstruction of two depositional areas: The Qaidam and Hexi Corridor basins, China. Tectonics 17, 823-842.

Meyer, B., Tapponnier, P., Bourjot, L., Metivier, F., Gaudemer, Y., Peltzer, G., 
1060

1061

1062

1063

1064

1065

1066

1067

1068

1069

1070

1071

1072

1073

1074

1075

1076

1077

1078

1079

1080

1081

Shunmin, G., Zhitai, C., 1998. Crustal thickening in Gansu - Qinghai, lithospheric mantle subduction, and oblique, strike-slip controlled growth of the Tibet plateau. Geophysical Journal International 135, 1-47.

Molnar, P., Tapponnier, P., 1975. Cenozoic tectonics of Asia: Effects of a continental collision. Science 189, 419-426.

Pei, J., Sun, Z., Wang, X., Zhao, Y., Ge, X., Guo, X., Li, H., Si, J., 2009. Evidence for Tibetan plateau uplift in Qaidam basin before Eocene-Oligocene boundary and its climatic implications. Journal of Earth Science 20, 430-437.

Peltzer, G., Tapponnier, P., 1988. Formation and evolution of strike-slip faults, rifts, and basins during the India-Asia collision: An experimental approach. Journal of Geophysical Research: Solid Earth (1978-2012) 93, 15085-15117.

QBGMR (Qinhai Bureau of Geology Mineral Resources), 1991. Regional Geology of Qinghai Province. Geological Publishing House, Beijing, pp. 1-662 (in Chinese).

Qi, C., Li, X., Liang, X., Liu, Y., Tu, X., 2005. High-precision measurement of Hf isotopic reference values for the U-Pb geochronology standard zircons by multi-collector inductively coupled plasma-mass spectrometry. Journal of Chinese Mass Spectrometry Society 26, 149-154.

Qiu, N.S., 2002. Tectono-thermal evolution of the Qaidam Basin, China: evidence from Ro and apatite fission track data. Petroleum Geoscience 8, 279-285.

Ritts, B.D., Hanson, A.D., Zinniker, D., Moldowan, J.M., 1999. Lower-Middle Jurassic nonmarine source rocks and petroleum systems of the northern Qaidam basin, northwest China. AAPG Bulletin 83, 1980-2005. 
Ritts, B.D., Biffi, U., 2000. Magnitude of post-Middle Jurassic (Bajocian) displacement on the central Altyn Tagh fault system, northwest China. Geological Society of America Bulletin 112, 61-74.

Ritts, B.D., Yue, Y., Graham, S.A., 2004. Oligocene-Miocene Tectonics and Sedimentation along the Altyn Tagh Fault, Northern Tibetan Plateau: Analysis of the Xorkol, Subei, and Aksay Basins. The Journal of geology 112, 207-229.

Roger, F., Arnaud, N., Gilder, S., Tapponnier, P., Jolivet, M., Brunel, M., Malavieille, J., Xu, Z., Yang, J., 2003. Geochronological and geochemical constraints on Mesozoic suturing in east central Tibet. Tectonics 22, 1037.

Roger, F., Jolivet, M., Malavieille, J., 2008. Tectonic evolution of the Triassic fold belts of Tibet. Comptes Rendus Geoscience 340, 180-189.

Roger, F., Jolivet, M., Malavieille, J., 2010. The tectonic evolution of the Songpan-Garzê (North Tibet) and adjacent areas from Proterozoic to Present: A synthesis. Journal of Asian Earth Sciences 39, 254-269.

Robinson, D.M., Dupont-Nivet, G., Gehrels, G.E., Zhang, Y., 2003. The Tula uplift, northwestern China: Evidence for regional tectonism of the northern Tibetan Plateau during late Mesozoic-early Cenozoic time. Geological Society of America Bulletin $115,35-47$.

Searle, M., 1996. Geological evidence against large-scale pre-Holocene offsets along the Karakoram Fault: Implications for the limited extrusion of the Tibetan plateau. Tectonics 15, 171-186.

Searle, M., Elliott, J., Phillips, R., Chung, S. L., 2011. Crustal-lithospheric structure 
and continental extrusion of Tibet. Journal of the Geological Society 168, 633-672.

Shang Erjie, 2001. Basic structural style of tertiary in the western part of the northern area in the Qaidam basin and its petroleum significance. Geoscience 12, 422-424 (in Chinese with English abstract).

Shi, R.D., Yang, J.S., Wu, C.L., Tsuyoshi, I., Takafumi, H., 2006. Island arc volcanic rocks in the north Qaidam UHP belt, northern Tibet plateau: Evidence for ocean-continent subduction preceding continent-continent Subduction. Journal of Asian Earth Sciences 28, 151-159.

Sobel, E.R., Arnaud, N., 1999. A possible middle Paleozoic suture in the Altyn Tagh, NW China. Tectonics 18, 64-74.

Sobel, E.R., Arnaud, N., Jolivet, M., Ritts, B.D., Brunel, M., 2001. Jurassic to Cenozoic exhumation history of the Altyn Tagh range, northwest China, constrained by ${ }^{40} \mathrm{Ar} /{ }^{39} \mathrm{Ar}$ and apatite fission track thermochronology. Geological Society of America Memoirs 194, 247-267.

Song, T., Wang, X., 1993. Structural styles and stratigraphic patterns of syndepositional faults in a contractional setting: Examples from Quaidam basin, northwestern China. AAPG bulletin 77, 102-117.

Song, S.G., Zhang, L.F., Niu, Y.L., Su, L., Song, B., Liu, D.Y., 2006. Evolution from oceanic subduction to continental collision: a case study from the Northern Tibetan Plateau based on geochemical and geochronological data. Journal of Petrology 47, 435-455.

Song, S., Niu, Y., Su, L., Zhang, C., Zhang, L., 2014. Continental orogenesis from 
ocean subduction, continent collision/subduction, to orogen collapse, and orogen recycling: The example of the North Qaidam UHPM belt, NW China. Earth-Science Reviews 129, 59-84.

Staisch, L.M., Niemi, N.A., Hong, C., Clark, M.K., Rowley, D.B., Currie, B., 2014. A Cretaceous - Eocene depositional age for the Fenghuoshan Group, Hoh Xil Basin: Implications for the tectonic evolution of the northern Tibet Plateau. Tectonics 33, 281-301.

Sun, Z.M., Yang, Z.Y., Pei, J.L., Ge, X.H., Wang, X.S., Yang, T.S., Li, W.M., Yuan, S.H., 2005. Magnetostratigraphy of Paleogene sediments from northern Qaidam Basin, China: implications for tectonic uplift and block rotation in northern Tibetan plateau. Earth and Planetary Science Letters 237, 635-646.

Sun, Z.C., Jing, M.C., Sun, N.D., Lu, Y.L., Cao, L., 2007. Discussion on boundary between the upper and lower members of Xiaganchaigou Formation of Paleogene in Well Kun-2, Qaidam Basin. Journal of Palaeogeography 9, 611-618 (in Chinese with English abstract).

Sun, Y., Chen, Z., Chen, B., Han F., Zhou, Y., Hao, R. and Li, S., 2014. Cenozoic Uplift and Denudation of the EW-trending Range of Northern Altun Mountains: Evidence from Apatite Fission Track Data. Acta Geoscientica Sinica 37, 67-75 (in Chinese with English abstract).

Tapponnier, P., Peltzer, G., Armijo, R., 1986. On the mechanics of the collision between India and Asia. Geological Society, London, Special Publications 19, 113-157. 
1148

1149

1150

1151

1152

1153

1154

1155

1156

1157

1158

1159

1160

1161

1162

1163

1164

1165

1166

1167

1168

1169

Tapponnier, P., Xu, Z.Q., Roger, F., Meyer, B., Arnaud, N., Wittlinger, G., Yang, J.S., 2001. Oblique stepwise rise and growth of the Tibet Plateau. Science 294, 1671-1677.

Thomas, W.A., 2011. Detrital-zircon geochronology and sedimentary provenance.

Lithosphere 3, 304-308.

Wang, E., 1997. Displacement and timing along the northern strand of the Altyn Tagh fault zone, northern Tibet. Earth and Planetary Science Letters 150, 55-64.

Wang, Y., Zhang, X., Wang, E., Zhang, J., Li, Q., Sun, G., $2005 .{ }^{40} \mathrm{Ar} /{ }^{39} \mathrm{Ar}$ thermochronological evidence for formation and Mesozoic evolution of the northern-central segment of the Altyn Tagh fault system in the northern Tibetan Plateau. Geological Society of America Bulletin 117, 1336-1346.

Wang, E., Xu, F.Y., Zhou, J.X., Wan, J., Burchfiel, B.C., 2006a. Eastward migration of the Qaidam basin and its implications for Cenozoic evolution of the Altyn Tagh fault and associated river systems. Geological Society of America Bulletin 118, 349-365.

Wang, C., Liu, L., Che, Z.C., Chen, D.L., Zhang, A.D., Luo, J.H., 2006b. U-Pb geochronology and tectonic setting of the granitic gneiss in Jianggaleisayi Eclogite Belt. Geological Journal of China Universities 12, 74-82 (in Chinese with English abstract).

Wang, L., Xiao, A.C., Gong, Q.L., Liu, D., Wu, L., Zhou, S.P., Shen, Z.Y., Lou, Q.Q., Sun, X.W., 2010. The unconformity in Miocene sequence of western Qaidam Basin and its tectonic significance. Science China Earth Sciences 53, 1126-1133 (in Chinese).

Wang, C., Liu, L., Yang, W.Q., Zhu, X.H., Cao, Y.T., Kang, L., Chen, S.F., Li, R.S., 
1170

1171

1172

1173

1174

1175

1176

1177

1178

1179

1180

1181

1182

1183

1184

1185

1186

1187

1188

1189

1190

1191

He, S.P., 2013. Provenance and ages of the Altyn Complex in Altyn Tagh: implications for the early Neoproterozoic evolution of northwestern China. Precambrian Research 230, 193-208.

Wang, C., Dai, J., Zhao, X., Li, Y., Graham, S.A., He, D., Ran, B., Meng, J., 2014a.

Outward-growth of the Tibetan Plateau during the Cenozoic: A review. Tectonophysics 621, 1-43.

Wang, C., Liu, L., Xiao, P.X., Cao, Y.T., Yu, H.Y., Meert, J.G., Liang, W.T., 2014b.

Geochemical and geochronologic constraints for Paleozoic magmatism related to the orogenic collapse in the Qimantagh-South Altyn region, northwestern China. Lithos 202-203, 1-20.

Wiedenbeck, M., Alle, P., Corfu, F., Griffin, W., Meier, M., Oberli, F., Quadt, A.v., Roddick, J., Spiegel, W., 1995. Three natural zircon standards for U-Th-Pb, Lu-Hf, trace element and REE analyses. Geostandards Newsletter 19, 1-23.

Wittlinger, G., Tapponnier, P., Poupinet, G., Mei, J., Danian, S., Herquel, G., Masson, F., 1998. Tomographic evidence for localized lithospheric shear along the Altyn Tagh fault. Science 282, 74-76.

Wu, C.L., Yang, J.S., Ireland, T., Wooden, J.L., Li, H.B., Wan, Y.S., Shi, R.D., 2001. Zircon SHRIMP ages of Aolaoshan granite from the south margin of Qilianshan and its geological significance. Acta Petrologica Sinica 17, 215-221 (in Chinese with English abstract).

Wu, C.L., Wooden, J.L., Robinson, P.T., Gao, Y.H., Wu, S.P., Chen, Q.L., Mazdab, F.K., Mattinson, C., 2009. Geochemistry and zircon SHRIMP U-Pb dating of 
1192

1193

1194

1195

1196

1197

1198

1199

1200

1201

1202

1203

1204

1205

1206

1207

1208

1209

1210

1211

1212

1213

granitoids from the west segment of the North Qaidam. Science China, Series D Earth Science 52, 1771-1790 (in Chinese).

Wu C. L., Gao Y. H., Lei M., Qin H. P., Liu C. H., Li M. Z., Frost. B. R., Wooden J. L., 2014. Zircon SHRIMP U-Pb dating, Lu-Hf isotopic characteristics and petrogenesis of the Palaeozoic granites in Mangya area, south Altun, NW China. Acta Petrologica Sinica 30, 2297-2323 (in Chinese with English abstract).

Wu, L., Xiao, A., Wang, L., Shen, Z., Zhou, S., Chen, Y., Wang, L., Liu, D., Guan, J., 2011. Late Jurassic-Early Cretaceous Northern Qaidam Basin, NW China: Implications for the earliest Cretaceous intracontinental tectonism. Cretaceous Research 32, 552-564.

Wu, L., Xiao, A.C., Yang, S.F., Wang, L.Q., Mao, L.G., Wang, L., Dong, Y.P., Xu, B., 2012a. Two-stage evolution of the Altyn Tagh Fault during the Cenozoic: new insight from provenance analysis of a geological section in NW Qaidam Basin, NW China. Terra Nova 24, 387-395.

Wu, L., Xiao, A., Wang, L., Mao, L., Wang, L., Dong, Y., Xu, B., 2012b. EW-trending uplifts along the southern side of the central segment of the Altyn Tagh Fault, NW China: Insight into the rising mechanism of the Altyn Mountain during the Cenozoic. Science China Earth Sciences 55, 926-939 (in Chinese).

Wu, L., Xiao, A., Ma, D., Li, H., Xu, B., Shen, Y., Mao, L., 2014. Cenozoic fault systems in southwest Qaidam Basin, northeastern Tibetan Plateau: Geometry, temporal development, and significance for hydrocarbon accumulation. AAPG bulletin 98, 1213-1234. 
1214

1215

1216

1217

1218

1219

1220

1221

1222

1223

1224

1225

1226

1227

1228

1229

1230

1231

1232

1233

1234

1235

Xia, W.C., Zhang, N., Yuan, X.P., Fan, L.S., Zhang, B.S., 2001. Cenozoic Qaidam basin, China: A stronger tectonic inversed, extensional rifted basin. AAPG bulletin 85, 715-736.

Xiao, W., Windley, B.F., Yong, Y., Yan, Z., Yuan, C., Liu, C., Li, J., 2009. Early Paleozoic to Devonian multiple-accretionary model for the Qilian Shan, NW China. Journal of Asian Earth Sciences 35, 323-333.

Xiao, Q., Shao, G., Liu-Zeng, J., Oskin, M.E., Zhang, J., Zhao, G., Wang, J., 2015.

Eastern termination of the Altyn Tagh Fault, western China: Constraints from a magnetotelluric survey. Journal of Geophysical Research: Solid Earth 120, 2838-2858.

XBGMR (Xinjiang Bureau of Geology and Mineral Resources), 1993. Regional Geology of Xinjiang Uygur Autonomous Region. Geological Publishing House, Beijing, pp. 1-841 (in Chinese with English abstract).

Yang, F., Ma, Z.Q., Xu, T.C., Ye, S.J., 1992. A Tertiary paleomagnetic stratigraphic profile in Qaidam basin. Acta Petrolei Sinica 13, 97-101 (in Chinese with English abstract).

Yang, J., Xu, Z., Song, S., Wu, C., Shi, R., Zhang, J., Wan, Y., Li, H., Jin, X., Jolivet, M., 2000. Discovery of eclogite in Dulan, Qinghai Province and its significance for studying the HP-UHP metamorphic belt along the central orogenic belt of China. Acta Geologica Sinica 74, 156-168 (in Chinese with English abstract).

Yang, J., Xu, Z., Zhang, J., Chu, C. Y., Zhang, R., Liou, J. G., 2001. Tectonic significance of early Paleozoic high-pressure rocks in Altun-Qaidam-Qilian 
Mountains, northwest China. Geological Society of America Memoirs 194, 151-170. Yang, M.H., Song, J.J., 2002. Petrology of the Lenghu granite mass, northwestern Qaidam basin, China. Northwestern Geol. 35, 94-98 (in Chinese with English abstract).

Yang, J.S., Wu, C.L., Zhang, J.X., Shi, R.D., Meng, F.C., Wooden, J.L., Yang, H.Y., 2006. Protolith of eclogites in the north Qaidam and Altun UHP terrane, NW China: Earlier oceanic crust? Journal of Asian Earth Sciences 28, 185-204.

Yang, W., Jolivet, M., Dupont-Nivet, G., Guo, Z., Zhang, Z., Wu, C., 2013. Source to sink relations between the Tian Shan and Junggar Basin (northwest China) from Late Palaeozoic to Quaternary: evidence from detrital U-Pb zircon geochronology. Basin Research 25, 219-240.

Yang, W., Jolivet, M., Dupont-Nivet, G., Guo, Z., 2014. Mesozoic - Cenozoic tectonic evolution of southwestern Tian Shan: Evidence from detrital zircon U/Pb and apatite fission track ages of the Ulugqat area, Northwest China. Gondwana Research 26, 986-1008.

Yin, A., Harrison, T.M., 2000. Geologic evolution of the Himalayan-Tibetan orogen. Annual Review of Earth and Planetary Sciences 28, 211-280.

Yin, A., Rumelhart, P., Butler, R., Cowgill, E., Harrison, T., Foster, D., Ingersoll, R., Qing, Z., Xian-Qiang, Z., Xiao-Feng, W., 2002. Tectonic history of the Altyn Tagh fault system in northern Tibet inferred from Cenozoic sedimentation. Geological Society of America Bulletin 114, 1257-1295.

Yin, A., Dang, Y.Q., Zhang, M., McRivette, M.W., Burgess, W.P., Chen, X.H., 2007. 
Cenozoic tectonic evolution of Qaidam basin and its surrounding regions (part 2): Wedge tectonics in southern Qaidam basin and the Eastern Kunlun Range. Geological Society of America Special Papers 433, 369-390.

Yin, A., Dang, Y.Q., Wang, L.C., Jiang, W.M., Zhou, S.P., Chen, X.H., Gehrels, G.E., McRivette, M.W., 2008a. Cenozoic tectonic evolution of Qaidam basin and its surrounding regions (Part 1): The southern Qilian Shan-Nan Shan thrust belt and northern Qaidam basin. Geological Society of America Bulletin 120, 813-846.

Yin, A., Dang, Y.Q., Zhang, M., Chen, X.H., McRivette, M.W., 2008b. Cenozoic tectonic evolution of the Qaidam basin and its surrounding regions (Part 3): Structural geology, sedimentation, and regional tectonic reconstruction. Geological Society of America Bulletin 120, 847-876.

Yu, X.J., Fu, S.T., Guan, S.W., Huang, B., Cheng, F., Cheng, X., Zhang, T., Guo, Z.J., 2014. Paleomagnetism of Eocene and Miocene sediments from the Qaidam basin: Implication for no integral rotation since the Eocene and a rigid Qaidam block. Geochemistry, Geophysics, Geosystems 15, 2109-2127.

Yuan, H.L., Gao, S., Liu, X.M., Li, H.M., Günther, D., Wu, F.Y., 2004. Accurate U-Pb age and trace element determinations of zircon by laser ablation - inductively coupled plasma-mass spectrometry. Geostandards and Geoanalytical Research 28, 353-370.

Yuan, D.Y., Ge, W.P., Chen, Z.W., Li, C.Y., Wang, Z.C., Zhang, H.P., Zhang, P.Z., Zheng, D.W., Zheng, W.J., Craddock, W.H., Dayem, K.E., Duvall, A.R., Hough, B.G., Lease, R.O., Champagnac, J.-D., Burbank, D.W., Clark, M.K., Farley, K.A., Garzione, C.N., Kirby, E., Molnar, P., Roe, G.H., 2013. The growth of northeastern Tibet and its 
relevance to large-scale continental geodynamics: A review of recent studies. Tectonics 32, 2013 TC003348.

Yue, Y.J., Liou, J.G., 1999. Two-stage evolution model for the Altyn Tagh fault, China. Geology 27, 227-230.

Yue, Y.J., Ritts, B.D., Graham, S.A., 2001. Initiation and long-term slip history of the Altyn Tagh Fault. International Geology Review 43, 1087-1093.

Yue, Y., Ritts, B.D., Graham, S.A., Wooden, J.L., Gehrels, G.E., Zhang, Z., 2004a. Slowing extrusion tectonics: lowered estimate of post-Early Miocene slip rate for the Altyn Tagh fault. Earth and Planetary Science Letters 217, 111-122.

Yue, Y.J., Ritts, B.D., Hanson, A.D., Graham, S.A., 2004b. Sedimentary evidence against large strike-slip translation on the Northern Altyn Tagh fault, NW China. Earth and Planetary Science Letters 228, 311-323.

Yue, Y.J., Graham, S.A., Ritts, B.D., Wooden, J.L., 2005. Detrital zircon provenance evidence for large-scale extrusion along the Altyn Tagh fault. Tectonophysics 406, 165-178.

Zhang, J.X., Zhang, Z.M., Xu, Z.Q., Yang, J.S., Cui, J.W., 2001. Petrology and geochronology of eclogites from the western segment of the Altyn Tagh, northwestern China. Lithos 56, 187-206.

Zhang, W., 2006. The High precise Cenozoic magnetostratigraphy of the Qaidam basin and uplift of the northern Tibetan Plateau. (Doctoral dissertation) Lanzhou University, Lanzhou, pp. 1-105 (in Chinese with English abstract).

Zhang, J.X., Li, H.K., Meng, F.C., Xiang, Z.Q., Yu, S.Y., Li, J.P., 2011. Polyphase 
tectonothermal events recorded in metamorphic basement from the Altyn Tagh, the southeastern margin of the Tarim basin, western China: constraint from U-Pb zircon geochronology -Pb zircon geochronology. Acta Petrologica Sinica 27, 23-46.

Zhang, Z.C., Guo, Z.J., Li, J.F., Tang, W.H., 2012. Mesozoic and Cenozoic uplift-denudation along the Altyn Tagh fault, northwestern china: constraints from apatite fission track data. Quaternary Sciences 32, 499-509 (in Chinese with English abstract).

Zhang, C.H., Cheng, F., Huang, G.P., Huang, Y.Q.., Xing, C., Guan, B., Zhang, Q.Y, and Xu, G., 2013a. Sediment and reservoir characteristics with reservoir evaluation of the Lulehe Formation in Qie 16 block of Kunbei oilfield in Qaidam Basin. Acta Petrolei Sinica 20, 2883-2894 (in Chinese with English abstract).

Zhang, W., Fang, X., Song, C., Appel, E., Yan, M., Wang, Y., 2013b. Late Neogene magnetostratigraphy in the western Qaidam Basin (NE Tibetan Plateau) and its constraints on active tectonic uplift and progressive evolution of growth strata. Tectonophysics 599, 107-116.

Zhang, J., Mattinson, C., Yu, S., Li, Y., 2014a. Combined rutile-zircon thermometry and U-Pb geochronology: New constraints on Early Paleozoic HP/UHT granulite in the south Altyn Tagh, north Tibet, China. Lithos 200, 241-257.

Zhang, H.P., Zhang, P.Z., Zheng, D.W., Zheng, W.., Chen, Z.W., Wang, W.T., 2014b. Transforming the Miocene Altyn Tagh fault slip into shortening of the north-western Qilian Shan: insights from the drainage basin geometry. Terra Nova 26, 216-221. Zhao, J.M., Mooney, W.D., Zhang, X.K., Li, Z.C., Jin, Z.J., Okaya, N., 2006. Crustal 
1324

1325

1326

1327

1328

1329

1330

1331

1332

1333

1334

1335

1336

1337

1338

1339

1340

1341

1342

structure across the Altyn Tagh Range at the northern margin of the Tibetan plateau and tectonic implications. Earth and Planetary Science Letters 241, 804-814.

Zhou, J.X., Xu, F.Y., Wang, T.C., Cao, A.F., Yin, C.M., 2006. Cenozoic deformation history of the Qaidam Basin, NW China: Results from cross-section restoration and implications for Qinghai-Tibet Plateau tectonics. Earth and Planetary Science Letters 243, 195-210.

Zhuang, G., Hourigan, J.K., Ritts, B.D., Kent-Corson, M.L., 2011. Cenozoic multiple-phase tectonic evolution of the northern Tibetan Plateau: Constraints from sedimentary records from Qaidam basin, Hexi Corridor, and Subei basin, northwest China. American Journal of Science 311, 116-152.

\section{Figure Caption}

Fig. 1 (A) SRTM based digital topographic map of the Tibetan plateau. (B) Digital elevation model (DEM) and major tectonic elements of the Altyn Tagh Range, the Qaidam basin and the surrounding regions. The location of Fig. 2 is identified by the solid box. The DEM map was generated from the $90 \mathrm{~m}$ SRTM data. Note that the yellow solid line refers to the location of seismic profile AA'. (C) Interpreted and (D) non-interpreted seismic profile AA'. Note that the succession of Cenozoic depo-centers is marked along the long axis of the basin. These depo-centers gradually migrated eastward since the Eocene.

Fig. 2 Simplified geological map of the northwestern Qaidam basin and eastern 
segment of the Altyn Tagh Range, adapted from the Geologic Map of the Tibetan plateau and adjacent areas compiled by the Chengdu Institute of Geology and Mineral Resources and Chinese Geological Survey (map scale, 1:1,500,000).

Fig. 3 Generalized stratigraphic column of the studied Mesozoic to Cenozoic series. Paleocurrent directions in the Huatugou section were obtained from Meng and Fang, (2008), Wu et al. (2012b) and Zhuang, et al. (2011). Paleocurrent directions in the Eboliang section were obtained from Zhuang, et al. (2011), Wu et al. (2012b) and Heermance et al. (2013). Note that sample CSL3 is cited from Cheng et al. (2015a), and samples HTG-E, HTG-N, CSL4, SZG1 and CSL5 are cited from Cheng et al. (2016). Red arrows refer to the general paleocurrent directions.

Fig. 4 Typical photomicrographs and field photographs of the various analyzed sediments. (A) Drill core sample of early to middle Jurassic $\left(\mathrm{J}_{1+2}\right)$ lithic sandstone obtained from drill well in the Eboliang section; (B) Thin section image of lithic sandstone from the Paleocene to early Eocene strata $\left(E_{1+2}\right)$ in the Eboliang section, under crossed polarized light. (C) Horizontally stratified sandstone interbedded with mudstones of the Xiaganchaigou Formation $\left(\mathrm{E}_{3}{ }^{1}\right)$ in the Eboliang section. (D) Thin section image of siltstone from the Oligocene strata $\left(\mathrm{N}_{1}\right)$, under crossed polarized light, obtained from drill well in the Eboliang section. (E) Thick-bedded sandstone in the early Miocene strata, Xiayoushashan Formation $\left(\mathrm{N}_{2}{ }^{1}\right)$, Eboliang section. (F) Thin section image of siltstone from the Pliocene strata $\left(\mathrm{N}_{2}{ }^{3}\right)$, in the Eboliang section, 
under crossed polarized light. (G) Greenish white sandstone intercalated with mudstone in the middle Eocene strata $\left(\mathrm{E}_{3}{ }^{1}\right)$, Huatugou section. $(\mathrm{H})$ Greenish white sandstone intercalated with brownish red mudstone in the late Eocene strata $\left(\mathrm{E}_{3}{ }^{1}\right)$, Huatugou section. (I) Thin section image of sandstone in the Oligocene strata $\left(\mathrm{N}_{1}\right)$, Huatugou section, under crossed polarized light.

Fig. 5 Representative CL images of zircons from the 11 sandstone samples. The yellow circles show the location of the U-Pb analysis. Numbers are U-Pb ages in Ma.

Fig. $6 \mathrm{U}-\mathrm{Pb}$ concordia diagrams for zircon grains of the 11 sandstone samples.

Fig. 7 Combined probability density functions (lines) and histogram plots (bars) depicting detrital zircon $\mathrm{U}-\mathrm{Pb}$ ages of samples from the Eboliang section, arranged in stratigraphic order. Age distributions are colored according to age groups, and the pie diagrams show percentages of grains in those age categories. Paleocurrents rose diagrams in black are compiled from Heermance et al. (2013) and rose diagrams in gray are compiled from Wu et al. (2012b) and Ritts and Biffi (2000).

Fig. 8 Combined probability density functions (lines) and histogram plots (bars) depicting detrital zircon $\mathrm{U}-\mathrm{Pb}$ ages of samples from the Huatugou section, arranged in stratigraphic order. Two distinctive age groups, indicative of separate sources, are colored. Paleocurrents rose diagrams are compiled from Meng and Fang, (2008), Wu 
et al. (2012b) and Zhuang, et al. (2011).

Fig. 9 (A) Sketched geological map of the Altyn Tagh Range and surrounding areas, showing the distribution of zircon U-Pb ages for granitoids. The numbers denote ages in Ma. Relative probability plots of zircon $\mathrm{U}-\mathrm{Pb}$ ages from basement rocks and intrusives in: (B) the Altyn Tagh Range, (C) the Qilian Shan, and (D) the Eastern Kunlun Range. Age data are mainly cited from: Guo and Li, (1999), Sobel and Arnaud, (1999), Yang et al. (2001), Zhang et al. (2001), Yang and Song, (2002), Cowgill et al. (2003), Gehrels et al. (2003a, 2003b), Jolivet et al. (2003), Lu and Yuan, (2003), Robinson et al. 2003, Roger et al. (2003), Chen et al. (2004), IGSQP, (2004), Yue et al. (2004, 2005), Liu et al. (2006), Shi et al. (2006), Song et al. (2006), Wang et al. (2006b), Yang et al. (2006), Lu et al. (2008), Roger et al. (2008), Bovet et al. (2009), Liu et al. (2009), Wu et al. (2009), Xiao et al. (2009), Roger et al. (2010), Zhang et al. (2011), Dai et al. (2013), Li et al. (2013), Wang et al. (2013), Long et al. (2014), Song et al (2014), Wang et al.(2014b) , Zhang et al. (2014a), Dong et al. (2014, 2015), Chen et al. (2015) and references therein. The blue arrow refers to the northeastward migration of the Huatugou and Eboliang sections from their origins. The red dashed line and the arrow show the $\sim 80 \mathrm{~km}$ elongation of the early Neoproterozoic intrusions in the Altyn Tagh range.

Fig. 10 (A) Frequency histograms for restricted early Neoproterozoic ages groups of detrital zircons from the Paleocene to early Eocene Lulehe Fm. $\left(E_{1+2}\right)$ and the Th/U 
ratio for those zircon ages. (B) CL images of zircons for all early Neoproterozoic ages zircons from the Paleocene to early Eocene Lulehe Fm. The yellow circles show the location of the U-Pb analysis. Numbers are U-Pb ages in Ma. Note that the $\sim 911 \mathrm{Ma}$ peak age for the Neoproterozoic ages groups coincides with the mean crystallization age of $~ 910$ Ma for the basement rocks in the western segment of the Altyn Tagh Range (Fig. 9A; Wang et al., 2013). The distinctive Th/U ratio and oscillatory zones for those zircons indicate magmatic sources.

Fig. 11 Seismic profiles in the southwestern Qaidam basin. See Fig. 2A for location. Note the fold and thrusts in seismic profile BB', indicating the deformation in the northwestern Qaidam basin since the early Miocene. Offset of the Paleogene strata in seismic profiles CC' and DD' indicates the Eocene to Oligocene deformation in the northwestern Qaidam basin which would be associated with deformation along the ATF. Growth strata of the post-Oligocene strata in seismic profiles BB' and CC' indicate intense tectonic movements along the ATF since the Miocene.

Fig. 12 Cenozoic kinematic model of the Altyn Tagh Fault and source to sink relation between the western Qaidam basin and the surrounding regions. (A) during the Paleocene to early Eocene, the basement rocks in the Altyn Tagh Range served as the major source for the clastic material deposited in the Eboliang section, while sediments in the Huatugou section were derived from the Eastern Kunlun Range; (B) during the early Eocene to the Oligocene, the Qaidam basin migrated northeastward 
1433 due to left-lateral strike-slip faulting along the ATF; (3) since the Miocene, intense 1434 left-lateral faulting along the ATF continuously offset the Qaidam basin towards the 1435 northeast and triggered post-Oligocene crustal deformation within the Altyn Tagh 1436 Range and western Qaidam basin. See text for detailed discussion.

1438 Table 1 Summary of the major characteristics and corresponding U-Pb age data for 1439 each sample. 